\title{
Synthesis of potential allosteric modulators of Hsp90 by chemical glycosylation of Eupomatenoid-6
}

\author{
Laura Morelli, Anna Bernardi, Sara Sattin* \\ Università degli Studi di Milano, Dipartimento di Chimica, via Golgi 19, 20133 Milano, Italy. \\ *corresponding author: E-mail address: sara.sattin@unimi.it, Phone: +390250314096
}

\section{Abstract}

Hsp90 (Heat shock protein-90) is a chaperone protein and an established anti-apoptotic target in cancer therapy. Most of the known small-molecule inhibitors that have shown potent antitumor activity target Hsp90 N-terminal domain and directly inhibit its ATP-ase activity. Many of these molecules display important secondary effects. A different approach consists in targeting the protein C-terminal domain (CTD), modulating its chaperone activity through allosteric effects. Using an original computational approach, allosteric hot-spots in the CTD have been recently identified that control interdomain communication. A combination of virtual and experimental screening allowed to select a rhamnosylated benzofuran (Eupomatenoid-2) as a lead for further development. In this paper we describe glycodiversification of Eupomatenoid-2 using chemical glycosylation of the 2-(4'-

hydroxyphenyl)benzofuran aglycon (a.k.a. Eupomatenoid-6). Glycosylation of the phenol by glycosyl bromides under basic conditions afforded the desired products in the gluco-galacto- and fuco-series. This approach failed in the manno- and rhamno-series. However, mannosylation and rhamnosylation of Eupomatenoid-6 could be obtained under carefully controlled acidic conditions, using $O$-benzoxazolyl imidate (OBox) donors. The glycosides obtained are currently under investigation as modulators of Hsp90 chaperone activity.

Keywords : Eupomatenoid, Phenol glycosylation, Hsp90, O-benzoxazolyl imidate (OBox), Glycodiversification, Phase Transfer Catalysis

\section{Introduction}

Heat Shock Proteins (HSPs) are a class of functionally related chaperone proteins, which are over expressed as a protective mechanism in cells exposed to a variety of stressful events. They have been shown to possess a pivotal role in cell cycle progression and cell death (apoptosis) and to be involved in many diseases. In particular, Hsp90 is nowadays established as an anti-apoptotic target in cancer therapy. ${ }^{1,2}$ Hsp90 consists of four domains, an N-terminal ATP binding site domain, a middle domain that regulates ATP hydrolysis, a charged region, and a C-terminal homodimerization domain. ${ }^{3}$ These domains are involved in complex internal dynamics processes that control the chaperone activity of the 
protein and, with it, the signaling pathways regulated by Hsp90, which controls a number of client proteins. $^{1,4}$

Hsp90 has numerous known small-molecule inhibitors that have shown potent antitumor activity in a wide-range of malignancies. ${ }^{5}$ Most of these molecules, such as Geldanamycin or Radicicol, ${ }^{6}$ target the Hsp90 N-terminal domain and directly inhibit its ATP-ase activity. The aminocoumarin Novobiocin and its analogues ${ }^{7,8}$ have been shown to bind the C-terminal domain (CTD) of Hsp90 and to cause proteosomal degradation of the clients by inhibiting correct folding. A recent study has shown that the activity and selectivity of Novobiocin can be tuned by glycosylation at $4{ }^{\prime}$ position. ${ }^{9}$ Using an original computational approach, ${ }^{10,11}$ allosteric hot-spots in Hsp90 CTD that control interdomain communication have been recently identified by Colombo and co-workers. Virtual screening allowed to discover a group of 14 molecules, targeted to these hot spots, six of which were experimentally shown to bind the CTD and to control Hsp90 function in cellular studies. ${ }^{11}$ Allosteric modulation of Hsp90 has the potential of tweaking the internal dynamics of the protein, leading to fine tuning of the signalling pathways it regulates. Thus, allosteric inhibitors or activators of Hsp90 activity may become useful tools for system biology studies.

Among the hits identified, ${ }^{11}$ we focused our attention on the rhamnosylated 2-(4'-hydroxyphenyl)-5propenyl-benzofuran scaffold $\mathbf{1}$ (Eupomatenoid-2, ${ }^{12}$ Figure 1). The aglyconic part is also known as Eupomatenoid-6 (2, Figure 1), a natural product extracted from the leaves of Piper fulvescens that has various known syntheses. ${ }^{13-16}$ Glycodiversification ${ }^{17-19}$ of $\mathbf{1}$ has the potential to generate a set of diverse modulators of Hsp90 activity..$^{9,20,21}$

In this paper, we report our studies on the chemical glycosylation of Eupomatenoid-6 (2).
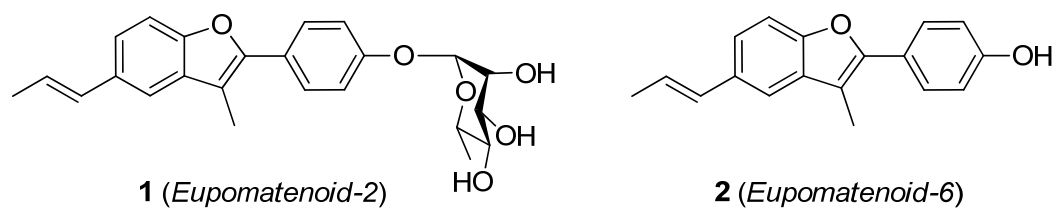

Figure 1. The rhamnosylated 2-phenyl-5-propenyl-benzofuran scaffold $\mathbf{1}$ and its aglycon $\mathbf{2}$.

\section{Results and discussion}

Eupomatenoid-6 (2) was prepared according to a reported procedure ${ }^{13}$ shown in Scheme 1, that starts from 2-bromo-4-chlorophenol $\mathbf{3}$ and leads to the intermediate 5-chlorobenzofuran $\mathbf{4}$, which is transformed in $\mathbf{2}$ using a Stille coupling. Due to the diasteroemeric purity of the Stille reagent used, the target 2 was obtained as a 3:1 E:Z mixture. 

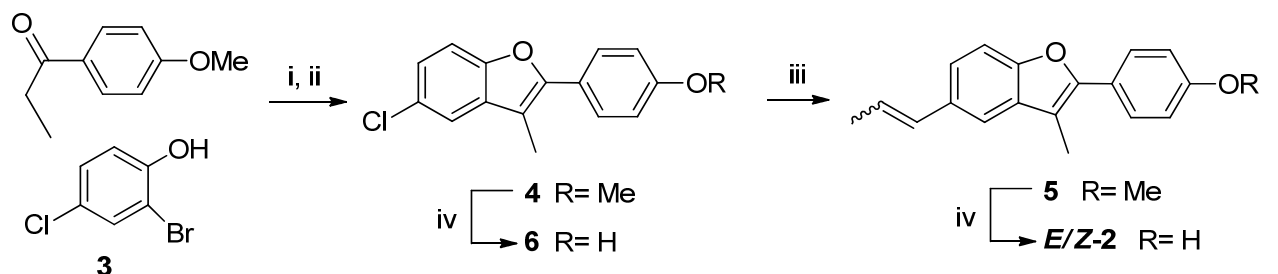

Scheme 1: Synthesis of Eupomatenoid-6 (2) and the glycosylation model aglycon 6. i. Pd(OAc) 2 , rac-2-(di-tertbutylphosphino)-1,1'-binaphthyl (rac-DTBPB), NaOtBu, toluene, MW $100^{\circ} \mathrm{C}, 1 \mathrm{~h}$; ii. TFA/DCM, r.t., $45 \%$ over two steps; iii. Tri- $N$-butyl(1-propenyl)tin, $\left[\mathrm{HPtBu}_{3}\right]\left[\mathrm{BF}_{4}\right] \mathrm{Pd}_{2} \mathrm{dba}_{3}, \mathrm{CsF}, 85 \%, E: Z 3: 1$; iv. NaSEt, DMF, $145^{\circ} \mathrm{C},>95 \%$.

For the exploration of different glycosylation strategies the 5-chlorobenzofuran 6 (Scheme 1) was chosen as a model aglycon, because it is synthetically more accessible than $\mathbf{2}$ and avoids the analysis of E:Z mixtures. Compound $\mathbf{6}$ was obtained in good yield by demethylation of $\mathbf{4}$ using sodium ethanthiolate. $^{13}$

Glycosylation of phenols is associated with several specific problems. ${ }^{22,23}$ First, under acidic conditions, phenols are weaker nucleophiles compared to alcohols, because the aromatic ring is electron withdrawing. Moreover, under classical Lewis acid catalyzed glycosylation conditions, $C$ - glycosylation competes with, or often prevails over, $\boldsymbol{O}$ - glycosylation. Nonetheless, acceptable yields can usually be obtained even with not very active glycosyl donors (such as $O$-acetates) using phenols carrying electrondonating groups (e.g., $p$-methoxyphenol). ${ }^{24}$

We initially tested the glycosylation of $\mathbf{6}$ with $\beta$-glucose penta-acetate $\mathbf{7}$ in the presence of boron trifluoride etherate ${ }^{24}$ and with $\alpha$-glucose tetra-O-acetyl-trichloroacetimidate $8^{25}$ in the presence of TMSOTf at $-20^{\circ} \mathrm{C}$ (Scheme 2). In both cases, 9 was isolated in low yields (24\% and $27 \%$ ) as a $6: 1(\beta: \alpha)$ anomeric mixture and extensive decomposition of the aglycon was observed.

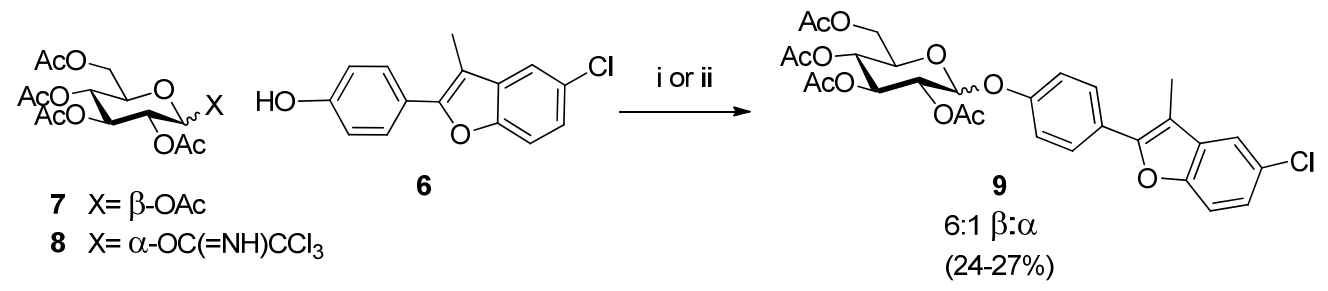

Scheme 2: Glycosylation of 6 under acidic conditions. i. 7 (1.5 eq), $\mathrm{BF}_{3} . \mathrm{Et}_{2} \mathrm{O}$ (3 eq), r.t. ii. 8 (1.2 eq), TMSOTf (0.1 eq), $-20^{\circ} \mathrm{C}$. 
The aglycon instability and the scarce reactivity under acidic conditions associated with poor stereoselectivity prompted us to examine glycosylation by glycosyl halide donors under basic conditions, where phenols are easily deprotonated. ${ }^{23}$

Glycosylation of model acceptor 6 with $\alpha$-glucosyl bromide tetra-O-acetate donor 10 was screened under different experimental conditions (Table 1). Reaction of 10 with $\mathbf{6}$ in the presence of excess silver carbonate afforded only traces of the expected product $\mathbf{9}$ ( $\beta$ anomer) and the acetylated acceptor $\mathbf{1 1}$ was recovered as the major product (Table 1, entry 1). Reaction of the Cs salt of $\mathbf{6}$ with excess 10 in DMF at $60^{\circ} \mathrm{C}$ led to recovery of unreacted starting material (Table 1, entry 2). Phase Transfer Catalysis (PTC) conditions were explored under various experimental set up. Tetrabutylammonium iodide (TBAI) was initially examined, using an excess ( 3 eq) of donor in $\mathrm{CHCl}_{3}$ as a solvent and aq. $\mathrm{K}_{2} \mathrm{CO}_{3}$ as the base, following a reported procedure ${ }^{26}$ (Table 1 , entry 3 ). Under these conditions the $\beta$-glycosylation product 9 was formed in good yields (60\%), but the conversion was not complete. Similar results were obtained using the more efficient catalyst tetrabutylammonium hydrogensulfate ( $\mathrm{TBAHSO}_{4}$ ) (entry 4, 65\% yield). Lowering the amount of donor (0.66 eq, entry 5) was beneficial for the chromatographic isolation of 9 , but worsened considerably the yields of the reaction. Indeed, it was more convenient to isolate the glycosylation product after deprotection ( $\mathrm{MeONa}$ ) to yield 9 a (Table 1, entry $6,60 \%$ yield over the two steps).

The anomeric configuration of $\mathbf{9}$ was assigned as $\beta$ after deacetylation to $\mathbf{9 a}$, which showed a $\mathrm{J}_{1,2}$ coupling constant of $7.3 \mathrm{~Hz}$ (DMSO- $\mathrm{d}_{6}$, Supplementary Figure 3). 
Table 1: Initial screening for optimal glycosylation conditions of acceptor $\mathbf{6}$ with donor $\mathbf{1 0}$

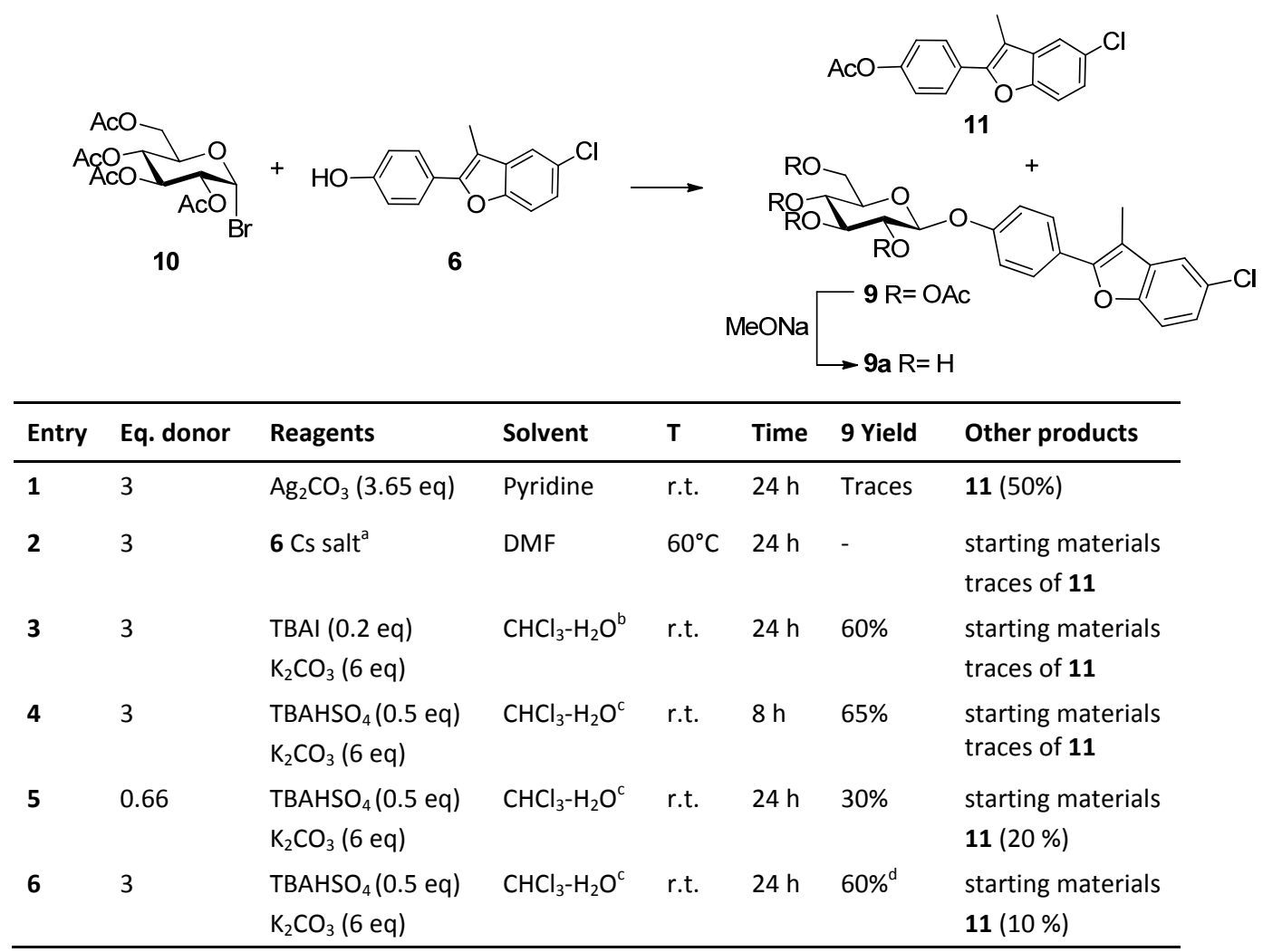

${ }^{\mathrm{a}}$ Generated with $\mathrm{Cs}_{2} \mathrm{CO}_{3}{ }^{\mathrm{b}} 0.04 \mathrm{M}, \mathrm{H}_{2} \mathrm{O}: 5 \% \mathrm{w} / \mathrm{w}_{\mathrm{K} 2 \mathrm{CO} 03} ;{ }^{\mathrm{c}} 0.1 \mathrm{M}, \mathrm{H}_{2} \mathrm{O}: 5 \% \mathrm{w} / \mathrm{w}_{\mathrm{K} 2 \mathrm{CO} 3} ;{ }^{\mathrm{d}}$ Yield calculated over 2 steps after deprotection to afford $\mathbf{9 a}$.

The reaction of different glycosyl bromide donors (L-GIC, D- and L-Gal and L-Fuc configuration) with 6 under the optimized conditions led to the desired products in modest to excellent yields (Table 2). An excess of donor or acceptor was used depending on the availability of the bromide. The fucosylated product was obtained in almost quantitative yield using an excess of donor (Table 2, entry 4). The anomeric configuration of all glycosylated products was confirmed to be $\beta$ only (18a-21a, Table 2) by experimental $\mathrm{NMR} \mathrm{J}_{\mathrm{H} 1, \mathrm{H} 2}$ coupling constants of the deacetylated products. 
Table 2: Glycosylation of acceptor 6 with different donors.

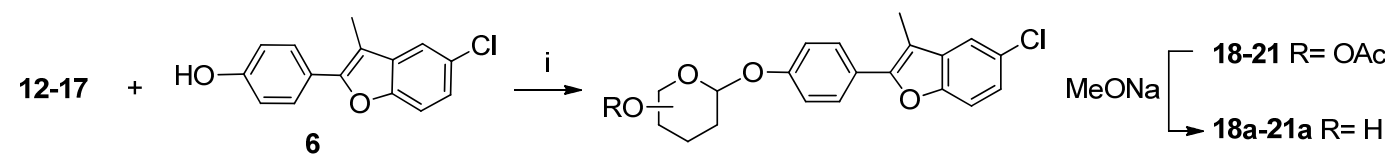

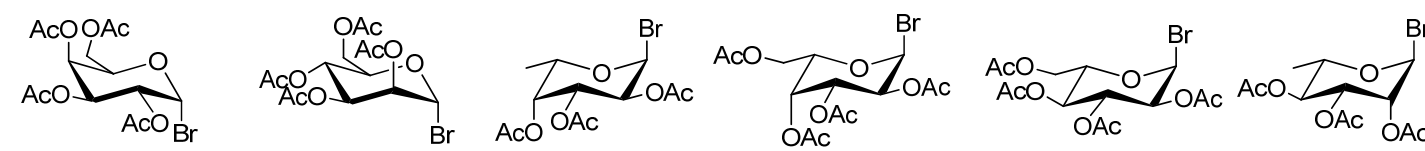
$\begin{array}{cccccc}\mathrm{D}-\mathrm{Gal}(\mathrm{OAc})_{4} \mathrm{Br} & \mathrm{D}-\mathrm{Man}(\mathrm{OAc})_{4} \mathrm{Br} & \mathrm{L}-\mathrm{Fuc}(\mathrm{OAc})_{3} \mathrm{Br} & \mathrm{L}-\mathrm{Gal}(\mathrm{OAc})_{4} \mathrm{Br} & \mathrm{L}-\mathrm{Glc}(\mathrm{OAc})_{4} \mathrm{Br} & \mathrm{L}-\mathrm{Rha}(\mathrm{OAc})_{3} \mathrm{Br} \\ 12 & 13 & 14 & 15 & 16 & 17\end{array}$

\begin{tabular}{|c|c|c|c|c|c|}
\hline Entry & Donor & Eq donor & Product & Isolated yield ${ }^{a}$ & By-products \\
\hline 1 & L-GIc $(\mathrm{OAc})_{4} \mathrm{Br}$ & 0.83 & $18 a$ & $36 \%(43 \%)^{b}$ & $11(30 \%)$ \\
\hline 2 & $\mathrm{D}-\mathrm{Gal}(\mathrm{OAc})_{4} \mathrm{Br}$ & 3 & $19 a$ & $41 \%^{b}$ & - \\
\hline 3 & L-Gal(OAc) $)_{4} \mathrm{Br}$ & 0.83 & 20 & $62 \%(77 \%)$ & traces of $\mathbf{1 1}$ \\
\hline 4 & $\mathrm{~L}-\mathrm{Fuc}(\mathrm{OAc})_{3} \mathrm{Br}$ & 3 & 21a & $>95 \%{ }^{\mathrm{b}}$ & - \\
\hline 5 & $\mathrm{D}-\mathrm{Man}(\mathrm{OAC})_{4} \mathrm{Br}$ & 0.66 & - & c & - \\
\hline 6 & $\mathrm{~L}-\mathrm{Rha}(\mathrm{OAc})_{4} \mathrm{Br}$ & 0.66 & - & c & - \\
\hline
\end{tabular}

i. $\mathrm{CHCl}_{3}(0.1-0.2 \mathrm{M}) /$ water $\left(5 \% \mathrm{w} / \mathrm{w}_{\mathrm{K} 2 \mathrm{CO} 3}\right), \mathrm{TBAHSO}_{4}(0.5 \mathrm{eq}), \mathrm{K}_{2} \mathrm{CO}_{3}(6 \mathrm{eq})$ at room temperature for $24 \mathrm{~h} .{ }^{\mathrm{a}}$ Yields in brackets are calculated based on the limiting agent. ${ }^{\mathrm{b}}$ Yield calculated over 2 steps after deprotection. ${ }^{\mathrm{c}}$ No reaction occurred.

Disappointingly, under these conditions glycosides of manno- configuration (D-Man and L-Rha) were not accessible, as only the unreacted starting material was recovered (Table 2, entries 5-6). To solve this problem, Mitsunobu conditions were initially explored treating 6 with tetra-O-benzoyl-rhamnose and $\mathrm{Ph}_{3} \mathrm{P},{ }^{27}$ but only unreacted starting material was recovered.

Attempts to glycosylate 6 with rhamnose penta-O-acetate in the presence of boron trifluoride etherate ${ }^{24}$ or with mannose tetra-O-benzoyl-trichloroacetimidate in the presence of TMSOTf were not successful. No reaction was observed in the first case, while $C$-glycosylation and aglycon decomposition were detected in the second case. Demchenko and co-workers recently reported a new class of glycosyl donors, the $O$-benzoxazolyl (OBox) imidates, ${ }^{28}$ that possess intermediate reactivity properties relative to $O$-trichloroacetimidates and thioglycosides. In particular OBox glycosides react with nucleophiles under Lewis acid activation at very low temperature, which may prevent degradation of our acid-sensitive acceptor. Following Demchenko procedure, a mixture of acceptor $(6)$ and the known ${ }^{28}$ donor $\alpha-D-$ 
$\operatorname{Man}(\mathrm{OBz})_{4}$-OBox 22 (1.2eq) was dissolved in 1,2-dichloroethane (1,2-DCE) and cooled to $-78^{\circ} \mathrm{C}$, with the solvent solidifying at $-35^{\circ} \mathrm{C}$. After addition of a $0.1 \mathrm{M}$ TMSOTf solution in 1,2-DCE $(0.1 \mathrm{eq})$ the reaction mixture was slowly warmed up to $-30^{\circ} \mathrm{C}$ and quenched by water addition after 2 min stirring. Work-up and chromatographic purification afforded product $\mathbf{2 3}$ as a single $(\alpha)$ isomer in $33 \%$ yield (Table 3, entry 1). Similarly, the unprecedented rhamnosyl donor $\mathbf{2 4}$ was prepared in $65 \%$ yield from tri-O-benzoyl- $\alpha$-Lrhamnosyl bromide $\mathbf{2 6}$ and AgOBox $\mathbf{2 7}$ (Scheme 3) and reacted with 6, providing product $\mathbf{2 5}$ in high yield (87\%, Table 3, entry 2). Zemplen deprotection of the $O$-Benzoyl glycosides followed by reverse phase automated chromatography afforded the corresponding glycosides 23a and 25a.

Table 3: TMSOTf-promoted glycosylation reaction of acceptors 6 with D-Man-OBox (22) and L-Rha-OBox (24).<smiles>CC(=O)O[Na]</smiles>

6<smiles>[R]OC1CCCC(Oc2ccc(-c3oc4ccc(Cl)cc4c3C)cc2)O1</smiles>

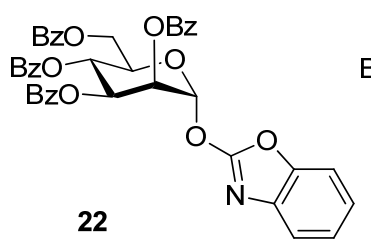

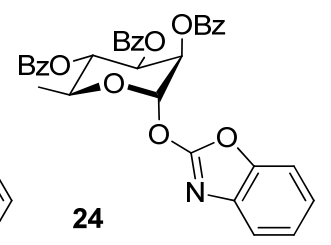

$\alpha-D-M a n \quad \alpha-L-R h a$

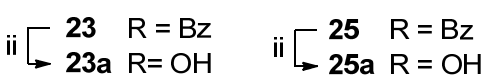

24

\begin{tabular}{ccccc}
\hline Entry & Acceptor & Donor (Eq) & Product & Isolated yield \\
\hline 1 & 6 & 22 & 23 & $33 \%$ \\
2 & 6 & 24 & 25 & $87 \%$ \\
\hline
\end{tabular}

i. 6 ( 1 eq, $0.2 \mathrm{M}$ in 1,2-DCE), 22 or 24 (1.2 eq), TMSOTf (0.1 eq), $-78^{\circ} \mathrm{C}$ to m.p., 5 min; ii. MeONa, MeOH, r.t.

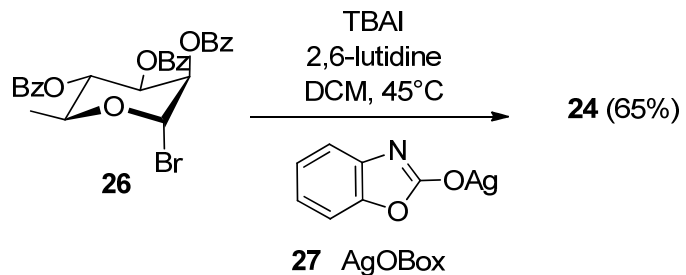

Scheme 3: Preparation of the unprecedented $\alpha-\mathrm{L}-\mathrm{Rha}(\mathrm{OBz})_{3}-\mathrm{OB}$ ox 24 by reaction of tri-O-benzoyl- $\alpha$-L-rhamnosyl bromide $\mathbf{2 6}$ with AgOBox 27.

Thus, with these two strategies in hands, scaffold $\mathbf{2}$ was glycosylated with different glycosyl donors. The OBox strategy was successfully applied for the preparation of the D-Man and L-Rha derivatives (28 and

29, respectively), which were obtained in moderate to good yields (Table 4, entries 1-2). 
When performing the reaction on the pure $E$ isomer of $\mathbf{2}(\boldsymbol{E}-\mathbf{2}$, Eupomatenoid-6), product $\boldsymbol{E}-\mathbf{2 9}$ was obtained in 70\% yield (Table 4, entry 3). Benzoate hydrolysis of $\boldsymbol{E}-\mathbf{2 9}$ under Zemplen conditions afforded $\alpha$-L-rhamnosyl 2-(4'-hydroxy-phenyl)-5-prop-1-E-enyl-benzofuran 1 (Eupomatenoid-2, quantitative yield) which was identical to an authentic sample obtained from the National Cancer Institute Collection ( $\mathrm{NCl}$ ). The $\alpha$ configuration of Eupomatenoid-2, previously assigned to the natural product without an unequivocal experimental evidence, ${ }^{12}$ was confirmed by analysis of ${ }^{1} \mathrm{H}$ coupling constants and of the ${ }^{1} \mathrm{H}$ NOESY spectrum: although an equilibrium between chair, skew and boat conformations might be present, spectral data support the hypothesis of a ${ }^{1} \mathrm{C}_{4}$ chair with strong nOe contacts for $\mathrm{H}_{1}$ only with $\mathrm{H}_{2}$ and $\mathrm{H}_{\text {ortho }}$ of the phenol moiety, as expected for an $\alpha$ product (see Supplementary Figure 13). Glycosylation of $\mathbf{2}$ under PTC conditions afforded the D-/L-GlC, D-/L-Gal and L-Fuc $\beta$ glycosides in moderate yields (Table 4). As shown in the model system, higher yields of the desired products were obtained using an excess of donor (Table 4, compare entries 4 and 5). Nonetheless, in some cases, an excess of acceptor was employed to simplify the purification procedure, since the glycosylation products often co-elute with the donor. For the same reason in some cases products were purified after deacetylationand yields are given over the two steps (Table 4, entries 6-8 and 10). 
Table 4: Glycosylation of acceptor 2 with different glycosyl donors.

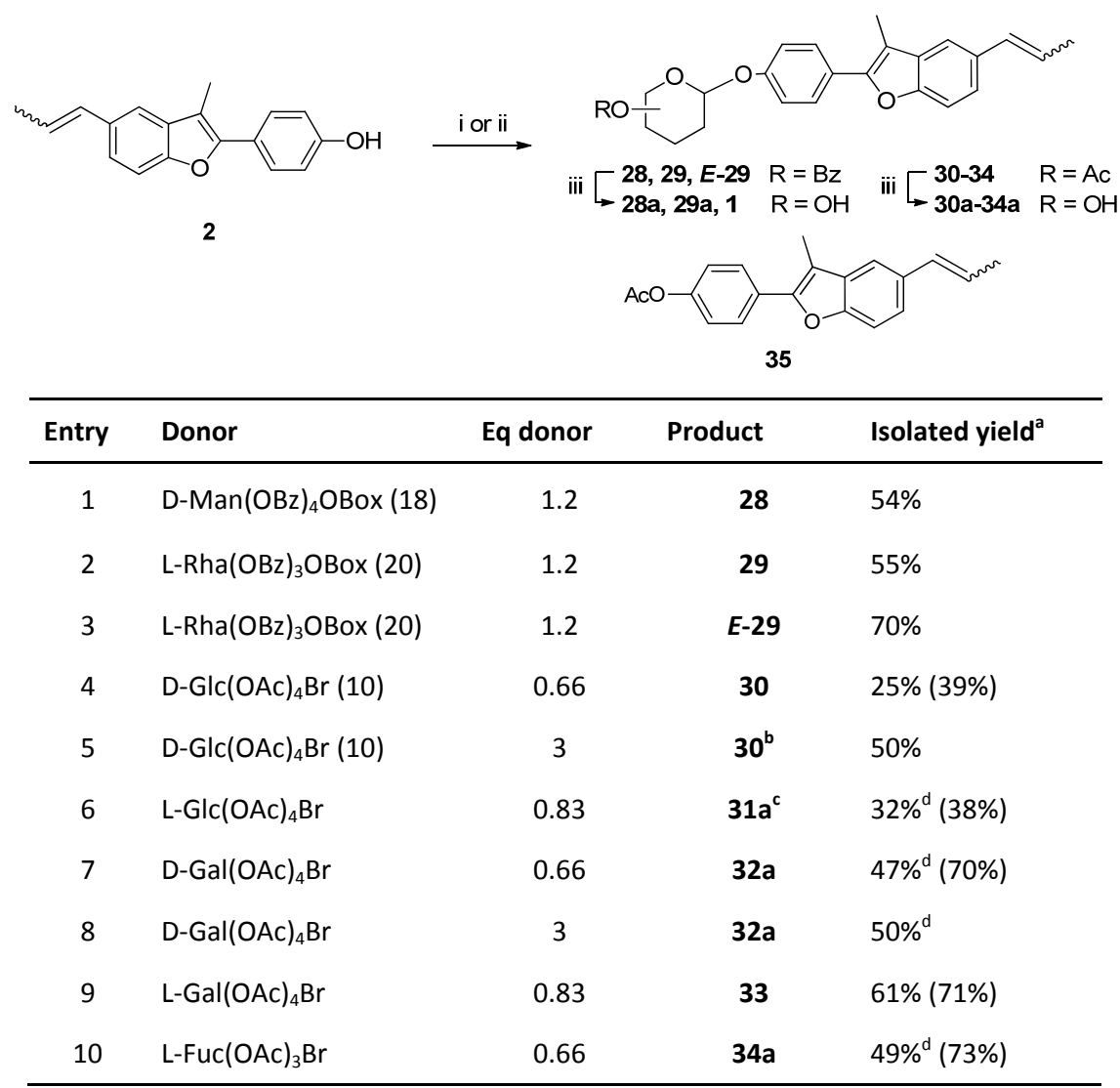

i. TMSOTf (0.1 eq), 1,2-DCE (0.2M), $-78^{\circ} \mathrm{C}$ to m.p., $5 \mathrm{~min}$; ii. $\mathrm{CHCl}_{3}(0.1-0.2 \mathrm{M}) /$ water $\left(5 \% \mathrm{w} / \mathrm{w}_{\mathrm{K} 2 \mathrm{CO}}\right)$, TBAHSO $_{4}(0.5$ eq), $\mathrm{K}_{2} \mathrm{CO}_{3}\left(6\right.$ eq) r.t., $24 \mathrm{~h}$; iii. $\mathrm{MeONa}, \mathrm{MeOH}$, r.t. ${ }^{a}$ Yields in brackets are calculated based on the limiting agent; ${ }^{\mathrm{b}} 35$ (20\%); ${ }^{\mathrm{c}} \mathbf{3 5}$ (30\%); ${ }^{\mathrm{d}}$ Yield calculated over 2 steps after deacetylation.

\section{Conclusions}

Chemical glycosylation of the phenol functionality of Eupomatenoid-6 (2) and of its synthetic precursor 6 was achieved from glycosyl halides under basic phase transfer conditions for the D- and L-gluco-, D- and L-galacto- and L-fuco-series. Products of manno- configuration (L-Rha and D-Man) were obtained using the corresponding OBox-imidate donor under Lewis acid catalysis at low temperature. In all cases 6deoxy sugars (L-Rha and L-Fuc) afforded the corresponding glycosides in considerably higher yields, as it is often been reported for chemical glycosylation of phenols. The anomeric configuration of the products was determined by NMR $\mathrm{J}_{\mathrm{H} 1-\mathrm{H} 2}$ coupling constant or, when this was not distinctive, by analysis of the nOe contacts. $\beta$-Glycosides were obtained in the gluco-, galacto- and fuco-series, $\alpha$-glycosides in the manno- and rhamno-series. 
The compounds syntesized have been preliminary tested for binding to Hsp90 C-terminal domain ${ }^{29}$ and several have been found to bind as well as Eupomatenoid-2. These molecules are currently being analyzed for allosteric modulation of Hsp90 function in cellular models.

\section{Experimental}

\subsection{General Methods}

All chemical reagents were of analytical grade, and used as supplied. Organic solvents were dried according to common literature protocols. All non-hydrolytic reactions were conducted under a positive pressure of nitrogen. Analytical thin layer chromatography (TLC) was performed on silica gel 60-F254 (Merck). Plates were visualized by ultraviolet (UV) light, or treatment with molibdic reagent solution, followed by heating. Compounds were purified by flash chromatography using Silica gel $60(0.040-0.063$ $\mathrm{mm}, 230-400$ mesh particle size) by Merck. Automated flash chromatography by Biotage instrument (Biotage Isolera ${ }^{\mathrm{TM}}$ Prime) was used to purify final compounds. KP-Sil ${ }^{\mathrm{TM}}$ (40-65 $\mu \mathrm{m}$, average 50 micron) Biotage SNAP cartridges were used for direct-phase purifications (for reverse-phase: KP-C18-HS ${ }^{\mathrm{TM}}$, average 25 micron); solvents were of reagent grade and were used as supplied. ${ }^{1} \mathrm{H}-\mathrm{NMR}$ spectra were recorded at $400 \mathrm{MHz}$ and ${ }^{13} \mathrm{C}-\mathrm{NMR}$ spectra were recorded at $100 \mathrm{MHz}$, using a Bruker Avance 400 instrument. Chemical shifts $(\delta)$ are reported in ppm using residual solvent signals from deuterated solvents as references. ${ }^{30}$ Signals in ${ }^{1} \mathrm{H}$ and ${ }^{13} \mathrm{C}$ NMR spectra were assigned with the aid of two dimensional COSY and HSQC spectra. For some signals in ${ }^{1} \mathrm{H}$ NMR spectra, the coupling patterns were reported as multiplets due to high order coupling or signal overlap. Mass spectrometry was performed under positive/negative-mode electrospray ionization (ESI) on a ThermoFinnigan LCQ $^{\text {TM }}$ Classic or Waters $^{\circledR}$ Micromass $^{\circledR}$ Q-Tof micro ${ }^{\text {TM }}$ Mass (ESI-HRMS) and for high resolution on Bruker Daltonics APEX II (FT-ICR). Optical rotations were measured in a $10 \mathrm{~cm}$ cell with a Perkin-Elmer 241 polarimeter at $25^{\circ} \mathrm{C}$. Compounds 3, 7, 10 and 12 are commercially available (Sigma-Aldrich). Compounds $\mathbf{1},{ }^{12} \mathbf{2 , 4}$ and 5, ${ }^{13}$ $13,{ }^{31} 14,{ }^{32} 15,{ }^{33} 16,{ }^{34} 17^{35}$ and $18^{28}$ are known. The characterization of protected glycosides $9,18-21,23$, 25, 28-34 is detailed in the supplementary information.

\subsection{General procedures}

\subsubsection{Glycosylation under phase transfer catalysis}

Peracetylated glycosyl bromide (3 eq) and 2-(4'-hydroxyphenyl)benzofuran (2 or 6, 1 eq) were dissolved in chloroform ( $10 \mathrm{~mL} / \mathrm{mmol})$. Tetrabutylammonium hydrogen sulfate $(0.5 \mathrm{eq})$, potassium carbonate $(6$ eq) and water ( $5 \% \mathrm{w} / \mathrm{w}$ of potassium carbonate) were added to the solution. The reaction mixture was stirred for $24 \mathrm{~h}$ at room temperature. The reaction mixture was diluted with chloroform, the organic 
layer was washed with $0.1 \mathrm{M} \mathrm{HCl}$, sat. $\mathrm{NaHCO}_{3}$ and brine, dried over anhydrous sodium sulfate and concentrated under vacuum. The crude product was purified by automated flash chromatography (hexane/ethyl acetate gradient elution).

\subsubsection{TMSOTf-promoted glycosylation with $O$-Benzoxazolyl imidates}

A mixture of glycosyl donor (1.2 eq) and aglycon (1 eq) in dry 1,2-dichloroethane $(5 \mathrm{~mL} / \mathrm{mmol})$ was stirred under nitrogen atmosphere at room temperature for $5 \mathrm{~min}$ and then cooled to $-78^{\circ} \mathrm{C}$. $\mathrm{A} 0.1 \mathrm{M}$ solution of TMSOTf (0.1 eq) in dry 1,2-dichloroethane was added to the frozen mixture. Since 1,2dichloroethane melts at $-35^{\circ} \mathrm{C}$, the reaction mixture was let warm to $-30 /-20^{\circ} \mathrm{C}$ and stirred for $2 \mathrm{~min}$ at this temperature. After the reaction was finished (TLC), the reaction mixture was diluted with $\mathrm{CH}_{2} \mathrm{Cl}_{2}$ and washed with $1 \%$ aq. $\mathrm{NaOH}$ and water. The organic phase was dried over anhydrous $\mathrm{Na}_{2} \mathrm{SO}_{4}$, and concentrated in vacuo. The residue was purified by column chromatography on silica gel (hexane/ethyl acetate gradient elution).

\subsubsection{General procedure for Zemplen hydrolysis of acetates/benzoates}

A $1 \mathrm{M}$ solution of sodium methoxide in dry methanol ( $0.5 \mathrm{eq} / \mathrm{O}$-cleavage) was drop-wise added to a solution of the peracetylated (or a suspension of the perbenzoylated) product in methanol (0.1 M). The reaction mixture was stirred for $1 \mathrm{~h}(2 \mathrm{~h}$ for $\mathrm{O}-\mathrm{Bz}$ ) at room temperature and then neutralized with IR-120 $\mathrm{H}^{+}$(Amberlite) resin. The resin was filtered off and the combined filtrate was concentrated in vacuo. The product was purified by reverse-phase automated flash chromatography (water/methanol gradient elution).

\subsection{Synthesized compounds}

\subsubsection{4-(5-Chloro-3-methyl-2-benzofuranyl)-phenol (6) Compound $4^{13}(710 \mathrm{mg}, 2.6 \mathrm{mmol})$ was} dissolved in dry DMF (13 mL). EtSNa (450 mg, $5.2 \mathrm{mmol}$ ) was added and the mixture was stirred at 145 ${ }^{\circ} \mathrm{C}$ for $4 \mathrm{~h}$. The reaction was cooled to r.t. and sat. $\mathrm{NH}_{4} \mathrm{Cl}$ was added $(10 \mathrm{~mL})$. The mixture was extracted with EtOAc and the combined organic layers were washed with $\mathrm{H}_{2} \mathrm{O}$ and brine, dried over anhydrous $\mathrm{Na}_{2} \mathrm{SO}_{4}$, filtered off and concentrated in vacuum. The residue was purified by column chromatography on silica gel (hexane/ethyl acetate gradient elution) to afford $662 \mathrm{mg}(98 \%)$ of the demethylated benzofuran 6. $R_{\mathrm{f}}=0.30(85: 15 \mathrm{Hex}: \mathrm{EtOAc}) ;{ }^{1} \mathrm{H} \mathrm{NMR}\left(400 \mathrm{MHz}, \mathrm{CDCl}_{3}\right) \delta 7.74-7.64(\mathrm{~m}, 2 \mathrm{H}, 2$ x H-m-PheO), 7.47 (dd, $J=2.1,0.5 \mathrm{~Hz}, 1 \mathrm{H}, \mathrm{H}-4 \mathrm{Bf}$ ), 7.36 (dd, $J=8.6,0.5 \mathrm{~Hz}, 1 \mathrm{H}, \mathrm{H}-7 \mathrm{Bf}$ ), 7.21 (dd, J= 8.6, 2.1 Hz, 1H, $\mathrm{H}-6 \mathrm{Bf}), 6.99-6.91(\mathrm{~m}, 2 \mathrm{H}, 2 \times \mathrm{H}-\mathrm{o}-\mathrm{Phe}-\mathrm{O}), 4.90(\mathrm{~s}, 1 \mathrm{H}, \mathrm{OH}), 2.40$ (s, 3H, CH 3 Bf). ${ }^{13} \mathrm{C} \mathrm{NMR}(101 \mathrm{MHz}$, $\mathrm{CDCl}_{3}$ ) $\delta 155.7$ ( $\mathrm{C}_{\text {quat. }}$-Phe-O), 152.3 (C-7a),152.1 (C-2), 132.9 (C-5),128.6 (2 x C-o-Phe-O), 128.0 ( quat. $^{-}$ Phe, C-3a), 124.1 (C-6), 118.9 (C-4), 115.8 (2 x C-m-Phe-O), 111.9 (C-7), 109.5 (C-3), 9.4 ( $\mathrm{CH}_{3}$ Bf). HRMS (ESI) calcd for $\mathrm{C}_{15} \mathrm{H}_{10} \mathrm{O}_{2} \mathrm{Cl}_{1}[\mathrm{M}-\mathrm{H}]^{-} 257.03748$, found 257.03747 . 
4.3.2 Benzoxazolyl 2,3,4-tri-O-benzoyl- $\alpha$-L-rhamnopyranoside (24) AgOBox ${ }^{28}$ (324 mg, 1.34mmol), 2,6-lutidine (117 $\mu \mathrm{L}, 1.00 \mathrm{mmol}$ ) and TBAI (14 mg, $0.04 \mathrm{mmol}$ ) were added to a solution of 2,3,4-Obenzoyl- $\alpha$-L-rhamnopyranosyl bromide $\left(363 \mathrm{mg}, 0.67 \mathrm{mmol}\right.$ ) in dry $\mathrm{CH}_{2} \mathrm{Cl}_{2}(4.5 \mathrm{~mL})$ under nitrogen atmosphere. The reaction mixture was stirred for $4 \mathrm{~h}$ at $50^{\circ} \mathrm{C}$ and then diluted with $\mathrm{CH}_{2} \mathrm{Cl}_{2}$ and washed with $1 \%$ aq. $\mathrm{NaOH}(2 \times 10 \mathrm{~mL})$, water $(2 \times 10 \mathrm{~mL})$ and brine $(10 \mathrm{~mL})$. The organic phase was dried over anhydrous $\mathrm{Na}_{2} \mathrm{SO}_{4}$, and concentrated in vacuo. The residue was purified by column chromatography on silica gel (hexane/ethyl acetate gradient elution) to afford $24\left(257 \mathrm{mg}, 65 \%\right.$ yield) as a white solid. $R_{\mathrm{f}}=$ 0.44 (8:2 Hex:EtOAc); $[\alpha]_{D}^{25}+40.3\left(c 1.0, \mathrm{CHCl}_{3}\right) ;{ }^{1} \mathrm{H}$ NMR $\left(\mathrm{CDCl}_{3}\right): \delta 8.11$ (d, J = 7.6 Hz, 2H, $\left.2 \times 0-\mathrm{CH}-\mathrm{Bz}\right)$, 7.99 (d, J = 7.8 Hz, 2H, $2 \times o-C H-B z), 7.84$ (d, J = 7.9 Hz, 2H, $2 \times o-C H-B z), 7.65$ (t, J = 7.3 Hz, 1H, p-CH-Bz), $7.60-7.50\left(\mathrm{~m}, 4 \mathrm{H}, 1 \times p-\mathrm{CH} \mathrm{Bz}, 2 \times m-\mathrm{CH} \mathrm{Bz}, \mathrm{H}-4_{\mathrm{Box}}\right), 7.50-7.40(\mathrm{~m}, 4 \mathrm{H}, 2 \times m-\mathrm{CH}-\mathrm{Bz}, 1 \times p-\mathrm{CH}-\mathrm{Bz}, \mathrm{H}-$ $\left.7_{\text {Box }}\right), 7.34-7.25\left(\mathrm{~m}, 4 \mathrm{H}, 2 \times m-\mathrm{CH}-\mathrm{Bz}, H-5_{\text {Box }}, H-6_{\text {Box }}\right), 6.57\left(\mathrm{~d}, 1 \mathrm{H}, J_{1,2}=1.1 \mathrm{~Hz}, H-1\right), 6.04-5.90(\mathrm{~m}, 2 \mathrm{H}$, $H-2, H-3), 5.79(\mathrm{t}, J=9.6 \mathrm{~Hz}, 1 \mathrm{H}, H-4), 4.44(\mathrm{dq}, J=12.3,6.1 \mathrm{~Hz}, 1 \mathrm{H}, H-5), 1.42\left(\mathrm{~d}, J=6.2 \mathrm{~Hz}, 3 \mathrm{H}, \mathrm{CH}_{3}-\mathrm{Rha}\right)$. ${ }^{13} \mathrm{C} \mathrm{NMR}\left(\mathrm{CDCl}_{3}\right): \delta 165.8$ (C=O Bz), 165.6 (C=O Bz), 165.4 (C=O Bz), 161.3 (C-2 Box), 148.7 (C-7a воx), 140.7

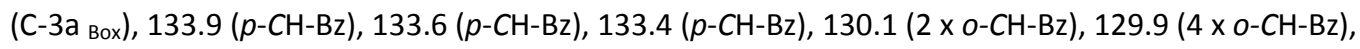
129.1 ( $\mathrm{C}_{\text {quat. }} \mathrm{Bz}$ ), 129.0 ( $2 \times \mathrm{C}_{\text {quat. }} \mathrm{Bz}$ ), 128.8 ( 2 x m-CH-Bz), 128.6 ( $\left.2 \times \mathrm{m}-\mathrm{CH}-\mathrm{Bz}\right), 128.5$ ( 2 x m-CH-Bz), 124.7

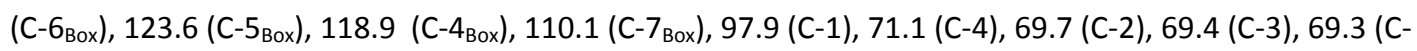
5), $17.8\left(\mathrm{CH}_{3}-\mathrm{Rha}\right)$. HRMS calcd for $\mathrm{C}_{34} \mathrm{H}_{27} \mathrm{~N}_{1} \mathrm{O}_{9} \mathrm{Na}_{1}[\mathrm{M}+\mathrm{Na}]^{+}$616.15780, found 616.15736.

\subsubsection{4-[3-methyl-5-(E-prop-1-enyl)benzofuran-2-yl]phenyl $\alpha$-L-rhamnopyranoside (1,}

Eupomatenoid-2) Compound 1 (42mg, $0.06 \mathrm{mmol}$ ) was prepared following general procedures 4.2.2 (E29, 70\%) and 4.2.3 (quant.) and it was isolated after automated flash chromatography purification (chloroform/methanol gradient elution). $R_{\mathrm{f}}=0.32\left(9: 1 \mathrm{CH}_{2} \mathrm{Cl}_{2}: \mathrm{CH}_{3} \mathrm{OH}\right) ;{ }^{1} \mathrm{H} \mathrm{NMR}\left(400 \mathrm{MHz}, \mathrm{CD}_{3} \mathrm{OD}\right) \delta$ $7.78-7.67$ (m, 2H, 2 x H-m-Phe-O), 7.43 (bs, 1H, H-4 Bf), 7.32 (d, J = 8.5 Hz, 1H, H-7 Bf), 7.27 (dd, J = 8.5, $1.5 \mathrm{~Hz}, 1 \mathrm{H}, \mathrm{H}-6 \mathrm{Bf}), 7.23-7.10$ (m, 2H, $2 \times \mathrm{H}-0-$ Phe-O), 6.50 (dd, $J=15.7,1.5 \mathrm{~Hz}, 1 \mathrm{H},=\mathrm{CH}-\mathrm{Ar}), 6.23$ (dq, J $=15.7,6.5 \mathrm{~Hz}, 1 \mathrm{H},=\mathrm{CH}-\mathrm{Me}), 5.51(\mathrm{bd}, J=1.5 \mathrm{~Hz}, 1 \mathrm{H}, \mathrm{H}-1), 4.04(\mathrm{dd}, J=3.3,1.8 \mathrm{~Hz}, 1 \mathrm{H}, \mathrm{H}-2), 3.88(\mathrm{dd}, J=$ 9.5, 3.4 Hz, 1H, H-3), 3.67 (tt, J=6.2, 4.6 Hz, 1H, H-5), 3.49 (t, J=9.5 Hz, 1H, H-4), $2.40\left(\mathrm{~s}, 3 \mathrm{H}, \mathrm{CH}_{3} \mathrm{Bf}\right)$, $1.88(\mathrm{dd}, J=6.6,1.5 \mathrm{~Hz}, 3 \mathrm{H}, \mathrm{Me}-\mathrm{CH}=), 1.26\left(\mathrm{~s}, 3 \mathrm{H}, \mathrm{CH}_{3} \mathrm{Rha}\right)$. ESI-MS calcd for $\mathrm{C}_{24} \mathrm{H}_{26} \mathrm{O}_{6} \mathrm{Na}_{1}[\mathrm{M}+\mathrm{Na}]^{+}$ 433.2, found 433.3; calcd for $\mathrm{C}_{48} \mathrm{H}_{51} \mathrm{O}_{12}[2 \mathrm{M}-\mathrm{H}]^{-} 819.3$, found 819.6.

4.3.4 4-[5-Chloro-3-methylbenzofuran-2-yl]phenoyl $\beta$-D-glucopyranoside (9a) Compound 9a (24 mg, $0.057 \mathrm{mmol}$ ) was prepared following general procedures 4.2.1 and 4.2.3 (60\% yield, over two steps). $R_{\mathrm{f}}=$ 0.23 (9:1 $\mathrm{CH}_{2} \mathrm{Cl}_{2}: \mathrm{CH}_{3} \mathrm{OH}$ ); $[\alpha]_{D}^{25}-55.0$ (c 0.1, Dioxane); ${ }^{1} \mathrm{H}$ NMR (400 MHz, MeOD) $\delta 7.80-7.69$ (m, 2H, $2 \mathrm{x}$ H-m-Phe-O), 7.54 (d, J = 2.1 Hz, 1H, H-4 Bf), 7.42 (d, J = 8.6 Hz, 1H, H-7 Bf), 7.27 - 7.20 (m, 3H, H-6 Bf, 2 x H-o-Phe-O), 5.00 (dd, J = 5.4, 2.1 Hz, 1H, H-1), 3.93 (dd, $J=12.1,2.0 \mathrm{~Hz}, 1 \mathrm{H}, \mathrm{H}-6 \mathrm{~b}$ ), 3.72 (dd, J = 12.1, 5.6 
$\mathrm{Hz}, 1 \mathrm{H}, \mathrm{H}-6 \mathrm{a}), 3.53-3.46$ (m, 3H, H-5, H-3, H-2), $3.45-3.38(\mathrm{~m}, 1 \mathrm{H}, \mathrm{H}-4), 2.42\left(\mathrm{~s}, 3 \mathrm{H}, \mathrm{CH}_{3} \mathrm{Bf}\right) .{ }^{13} \mathrm{C} N M R$ (101 MHz, MeOD) $\delta 159.2$ (C quat.-Phe-O), 153.5 (C-7a Bf), 153.4 (C-2 Bf), 134.0 (C-5 Bf), 129.2 (2 x C-mPhe-O), 126.3 (C-3a Bf, C quat.-Phe), 125.2 (C-6 Bf), 119.8 (C-4 Bf), 117.9 (2 x C-o-Phe-O), 112.8 (C-7 Bf), 110.9 (C-3 Bf), 102.1 (C-1), 78.2 (C-5), 78.0 (C-3), 74.9 (C-2), 71.3 (C-4), 62.5 (C-6), 9.3 (CH $\mathrm{CH}_{3}$ Bf). ${ }^{1} \mathrm{H}$ NMR (400 MHz, DMSO-d6) $\delta 7.78-7.71$ (m, 3H, 2 x H-m-Phe-O, H-4 Bf), 7.59 (d, J = 8.7 Hz, 1H, H-7 Bf), 7.31 (dd, $J=8.7,2.2 \mathrm{~Hz}, 1 \mathrm{H}, \mathrm{H}-6 \mathrm{Bf}$ ), 7.20 (d, $J=8.9 \mathrm{~Hz}, 2 \mathrm{H}, 2 \times \mathrm{H}-o-P h e-O), 5.36$ (d, J=4.5 Hz, 1H, OH-2), 5.13 (d, J=4.3 Hz, 1H, OH-3), 5.06 (d, J = 5.2 Hz, 1H, OH-4), 4.96 (d, J= 7.3 Hz, 1H, H-1), 4.58 (t, J=5.7 Hz, 1H, OH-6), $3.76-3.65$ (bddd, $1 \mathrm{H}, J=11.7,5.7,1.5 \mathrm{~Hz}, 1 \mathrm{H}, \mathrm{H}-6 \mathrm{a}), 3.48$ (dt, J=11.7, $5.9 \mathrm{~Hz}, 1 \mathrm{H}, \mathrm{H}-6 \mathrm{~b}$ ), $3.42-$ $3.34(\mathrm{~m}, 1 \mathrm{H}, \mathrm{H}-5), 3.33-3.11(\mathrm{~m}, 6 \mathrm{H}, \mathrm{H}-3, \mathrm{H}-2, \mathrm{H}-4), 2.41$ (s, 3H, $\left.\mathrm{CH}_{3} \mathrm{Bf}\right)$. HRMS (ESI) calcd for $\mathrm{C}_{21} \mathrm{H}_{21} \mathrm{O}_{7} \mathrm{Cl}_{1} \mathrm{Na}_{1}[\mathrm{M}+\mathrm{Na}]^{+}$443.08683, found 443.08705.

\subsubsection{4-[5-Chloro-3-methylbenzofuran-2-yl]phenoyl $\beta$-L-glucopyranoside (18a) Compound 18a (40}

$\mathrm{mg}, 0.094 \mathrm{mmol}$ ) was prepared following general procedures 4.2.1 and 4.2.3 (43\% yield, over two steps). $R_{\mathrm{f}}=0.23\left(9: 1 \mathrm{CH}_{2} \mathrm{Cl}_{2}: \mathrm{CH}_{3} \mathrm{OH}\right) ;[\alpha]_{\mathrm{D}}^{25}+55$ (c 0.1, Dioxane). ${ }^{1} \mathrm{H} \mathrm{NMR}\left(400 \mathrm{MHz}, \mathrm{CD}_{3} \mathrm{OD}\right) \delta 7.80-7.69(\mathrm{~m}, 2 \mathrm{H}$, 2 x H-m-Phe-O), 7.56 (d, J = 1.9 Hz, 1H, H-4 Bf), 7.44 (d, J = 8.6 Hz, 1H, H-7 Bf), $7.27-7.20$ (m, 3H, H-6 Bf, $2 \times$ H-o-Phe-O), 5.02 (dd, $J=5.4,2.0 \mathrm{~Hz}, 1 \mathrm{H}, \mathrm{H}-1$ ), 3.94 (dd, J=12.1, $2.0 \mathrm{~Hz}, 1 \mathrm{H}, \mathrm{H}-6 \mathrm{~b}$ ), 3.74 (dd, J = 12.1, $5.6 \mathrm{~Hz}, 1 \mathrm{H}, \mathrm{H}-6 \mathrm{a}), 3.58-3.38(\mathrm{~m}, 4 \mathrm{H}, \mathrm{H}-5, \mathrm{H}-3, \mathrm{H}-2, \mathrm{H}-4), 2.43$ (s, 3H, $\mathrm{CH}_{3} \mathrm{Bf}$ ). ESI-MS calcd for $\mathrm{C}_{21} \mathrm{H}_{21} \mathrm{O}_{7} \mathrm{Cl}_{1} \mathrm{Na}_{1}[\mathrm{M}+\mathrm{Na}]^{+}$443.1, found 443.3; calcd for $\mathrm{C}_{42} \mathrm{H}_{42} \mathrm{O}_{14} \mathrm{Cl}_{2} \mathrm{Na}_{1}[2 \mathrm{M}+\mathrm{Na}]^{+}$863.2, found 863.1; calcd for $\mathrm{C}_{42} \mathrm{H}_{41} \mathrm{O}_{14} \mathrm{Cl}_{2}[2 \mathrm{M}-\mathrm{H}]^{-} 839.2$, found 839.3.

4.3.6 4-[5-Chloro-3-methylbenzofuran-2-yl]phenyl $\beta$-D-galactopyranoside (19a) Compound 19a (29 $\mathrm{mg}, 0.07 \mathrm{mmol}$ ) was prepared following general procedures 4.2 .1 and 4.2 .3 (41\% yield, over two steps). $R_{\mathrm{f}}=0.25$ (9:1 $\left.\mathrm{CH}_{2} \mathrm{Cl}_{2}: \mathrm{CH}_{3} \mathrm{OH}\right) ;[\alpha]_{\mathrm{D}}^{25}-52$ (c 0.15, Dioxane). ${ }^{1} \mathrm{H}$ NMR (400 MHz, $\left.\mathrm{CD}_{3} \mathrm{OD}\right) \delta 7.78-7.71$ (m, $2 \mathrm{H}, 2 \times \mathrm{H}-m$-Phe-O), 7.54 (d, J= $1.9 \mathrm{~Hz}, 1 \mathrm{H}, \mathrm{H}-4 \mathrm{Bf}$ ), 7.43 (d, J = 8.9 Hz, 1H, H-7 Bf), $7.29-7.22$ (m, 3H, H$6 \mathrm{Bf}, 2 \times \mathrm{H}-\mathrm{o}-\mathrm{Phe}-\mathrm{O}), 4.96(\mathrm{~d}, J=7.7 \mathrm{~Hz}, 1 \mathrm{H}, \mathrm{H}-1), 3.93(\mathrm{~d}, J=3.2 \mathrm{~Hz}, 1 \mathrm{H}, \mathrm{H}-4), 3.87-3.70(\mathrm{~m}, 4 \mathrm{H}, \mathrm{H}-2, \mathrm{H}-$ $6 a, H-6 b, H-5), 3.61$ (dd, $J=9.7,3.4 \mathrm{~Hz}, 1 \mathrm{H}, \mathrm{H}-3$ ), 2.42 (s, 3H, $\mathrm{CH}_{3} \mathrm{Bf}$ ). ${ }^{13} \mathrm{C} N M R\left(101 \mathrm{MHz}, \mathrm{CD}_{3} \mathrm{OD}\right) \delta$

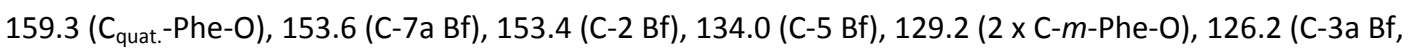

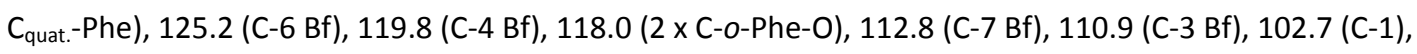
77.1 (C-5), 74.9 (C-3), 72.2 (C-2), 70.2 (C-4), 62.5 (C-6), 9.3 ( $\mathrm{CH}_{3} \mathrm{Bf}$ ). HRMS (ESI) calcd for $\mathrm{C}_{21} \mathrm{H}_{21} \mathrm{O}_{7} \mathrm{Cl}_{1} \mathrm{Na}_{1}$ $[\mathrm{M}+\mathrm{Na}]^{+} 443.08680$, found 443.08682 .

\subsubsection{4-[5-Chloro-3-methylbenzofuran-2-yl]phenoyl $\beta$-L-galactopyranoside (20a) Compound 20a (55}

$\mathrm{mg}, 0.13 \mathrm{mmol}$ ) was prepared following general procedures $4.2 .1(\mathbf{1 4}, 77 \%)$ and 4.2 .3 (quant. yield). $R_{\mathrm{f}}=$ 0.25 (9:1 $\left.\mathrm{CH}_{2} \mathrm{Cl}_{2}: \mathrm{CH}_{3} \mathrm{OH}\right) ;[\alpha]_{\mathrm{D}}^{25}+52.0$ (c 0.1, Dioxane). ${ }^{1} \mathrm{H}$ NMR (400 MHz, CD $\left.{ }_{3} \mathrm{OD}\right) \delta 7.78-7.71$ (bd, $2 \mathrm{H}, 2$ x H-m-Phe-O), $7.55-7.52$ (bd, 1H, H-4 Bf), $7.45-7.40$ (bd, 1H, H-7 Bf), $7.28-7.20$ (bs, 3H, H-6 Bf, 2 x Ho-Phe-O), 4.96 (d, J = 7.7 Hz, 1H, H-1), 3.93 (d, J = 3.4 Hz, 1H, H-4), 3.88-3.70 (m, 4H, H-2, H-6a, H-6b, H- 
5), $3.66-3.57(\mathrm{~m}, 1 \mathrm{H}, \mathrm{H}-3), 2.42\left(\mathrm{~s}, 1 \mathrm{H}, \mathrm{CH}_{3} \mathrm{Bf}\right)$. ESI-MS calcd for $\mathrm{C}_{21} \mathrm{H}_{21} \mathrm{O}_{7} \mathrm{Cl}_{1} \mathrm{Na} \mathrm{a}_{1}[\mathrm{M}+\mathrm{Na}]^{+} 443.1$, found 443.3; calcd for $\mathrm{C}_{42} \mathrm{H}_{42} \mathrm{O}_{14} \mathrm{Cl}_{2} \mathrm{Na}_{1}[2 \mathrm{M}+\mathrm{Na}]^{+}$863.2, found 863.2; calcd for $\mathrm{C}_{42} \mathrm{H}_{41} \mathrm{O}_{14} \mathrm{Cl}_{2}[2 \mathrm{M}-\mathrm{H}]^{-} 839.2$, found 839.1 .

4.3.8 4-[5-Chloro-3-methylbenzofuran-2-yl]phenyl $\beta$-L-fucopyranoside (21a) Compound 21a (35 mg, $0.088 \mathrm{mmol}$ ) was prepared following general procedures $4.2 .1(\mathbf{2 1},>95 \%)$ and 4.2 .3 (quant. yield). $R_{\mathrm{f}}=$ 0.58 (9:1 $\mathrm{CH}_{2} \mathrm{Cl}_{2}: \mathrm{CH}_{3} \mathrm{OH}$ ); $[\alpha]_{\mathrm{D}}^{25}+52.0$ (c 0.1, Dioxane). ${ }^{1} \mathrm{H} \mathrm{NMR}\left(400 \mathrm{MHz}, \mathrm{CD}_{3} \mathrm{OD}\right) \delta 7.79-7.70$ (m, $2 \mathrm{H}, 2$ x H-m-Phe-O), 7.54 (d, J = 2.0 Hz, 1H, H-4 Bf), 7.42 (d, J = 8.6 Hz, 1H, H-7 Bf), 7.29 - 7.13 (m, 3H, H-6 Bf, 2 x H-o-Phe-O), 4.94 (d, J = 7.7 Hz, 1H, H-1), $3.93-3.83(\mathrm{~m}, 1 \mathrm{H}, \mathrm{H}-5), 3.79$ (dd, J = 9.7, 7.7 Hz, 1H, H-2), $3.69(\mathrm{bd}, J=2.9 \mathrm{~Hz}, 1 \mathrm{H}, \mathrm{H}-4), 3.61$ (dd, $J=9.7,3.4 \mathrm{~Hz}, 1 \mathrm{H}, \mathrm{H}-3), 2.42\left(\mathrm{~s}, 3 \mathrm{H}, \mathrm{CH}_{3} \mathrm{Bf}\right), 1.33$ (d, $J=6.5 \mathrm{~Hz}$, 3H, $\mathrm{CH}_{3}$ Fuc). ${ }^{13} \mathrm{C}$ NMR (101 MHz, CD 3 OD) $\delta 159.3$ (C quat.-Phe-O), 153.6 (C-7a Bf), 153.4 (C-2 Bf), 134.0 (C5 Bf), 129.1 ( 2 × C-m-Phe-O), 126.2 (C-3a Bf, C quat.-Phe), 125.2 (C-6 Bf), 119.8 (C-4 Bf), 117.9 (2 x C-o-PheO), 112.8 (C-7 Bf), 110.9 (C-3 Bf), 102.4 (C-1), 75.0 (C-3), 72.9 (C-4), 72.3 (C-5), 72.0 (C-2), 16.8 ( $\mathrm{CH}_{3}$ Fuc), $9.3\left(\mathrm{CH}_{3}\right.$ Bf). HRMS (ESI) calcd for $\mathrm{C}_{21} \mathrm{H}_{21} \mathrm{Cl}_{1} \mathrm{O}_{6} \mathrm{Na}_{1}[\mathrm{M}+\mathrm{Na}]^{+} 427.09189$, found 427.09228.

\subsubsection{4-[5-Chloro-3-methylbenzofuran-2-yl]phenyl $\alpha$-D-mannopyranoside (23a) Compound 23a (9} $\mathrm{mg}, 0.02 \mathrm{mmol}$ ) was prepared following general procedures $4.2 .2(23,33 \%)$ and $4.2 .3(52 \%)$ and it was isolated after automated flash purification (chloroform/methanol gradient elution). $R_{\mathrm{f}}=0.27$ (9:1 $\mathrm{CH}_{2} \mathrm{Cl}_{2}: \mathrm{CH}_{3} \mathrm{OH}$ ); $[\alpha]_{D}^{25}+85.0$ (c 0.1, Dioxane). ${ }^{1} \mathrm{H}$ NMR (400 MHz, CD $\left.3 \mathrm{OD}\right) \delta 7.78-7.71$ (m, 2H, $2 \times \mathrm{H}-m-$ Phe-O), $7.54-7.52$ (m, 1H, H-4 Bf), $7.44-7.39$ (m, 1H, H-7 Bf), 7.29- 7.21 (m, 3H, H-6 Bf, 2 x H-o-PheO), 5.57 (d, $J=1.6 \mathrm{~Hz}, 1 \mathrm{H}, \mathrm{H}-1$ ), 4.04 (bdd, $J=3.3,1.8 \mathrm{~Hz}, 1 \mathrm{H}, \mathrm{H}-2$ ), 3.93 (dd, J= 9.4, $3.4 \mathrm{~Hz}, 1 \mathrm{H}, \mathrm{H}-3$ ), 3.85 $-3.68(\mathrm{~m}, 3 \mathrm{H}, \mathrm{H}-4, \mathrm{H}-6 \mathrm{a}, \mathrm{H}-6 \mathrm{~b}), 3.66-3.55(\mathrm{~m}, 1 \mathrm{H}, \mathrm{H}-5), 2.41$ (s, 3H, $\left.\mathrm{CH}_{3} \mathrm{Bf}\right) .{ }^{13} \mathrm{C} N M R(101 \mathrm{MHz}$, $\mathrm{CD}_{3} \mathrm{OD}$ ) $\delta 158.0$ ( $\mathrm{C}_{\text {quat. }}$-Phe-O), 153.5 (C-7a Bf), 153.4 (C-2 Bf), 134.0 (C-5 Bf), 129.2 (2 x C-m-Phe-O), 126.2 (C-3a Bf, Cquat.-Phe), 125.2 (C-6 Bf), 119.8 (C-4 Bf), 118.0 (2 x C-o-Phe-O), 112.8 (C-7 Bf), 111.0 (C-3

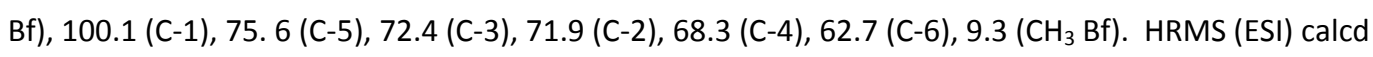
for $\mathrm{C}_{21} \mathrm{H}_{21} \mathrm{O}_{7} \mathrm{Cl}_{1} \mathrm{Na}_{1}[\mathrm{M}+\mathrm{Na}]^{+} 443.08680$, found 443.08718 .

4.3.10 4-[5-Chloro-3-methylbenzofuran-2-yl]phenyl $\alpha$-L-rhamnopyranoside (25a) Compound 25a (36 $\mathrm{mg}, 0.09 \mathrm{mmol}$ ) was prepared following procedures $4.2 .2(25,87 \%)$ and 4.2 .3 (quant.). $R_{\mathrm{f}}=0.50$ (9:1 $\mathrm{CH}_{2} \mathrm{Cl}_{2}: \mathrm{CH}_{3} \mathrm{OH}$ ); $[\alpha]_{D}^{25}-124.7$ (c 0.1, Dioxane). ${ }^{1} \mathrm{H}$ NMR (400 MHz, $\left.\mathrm{CD}_{3} \mathrm{OD}\right) \delta 7.72-7.66$ (m, 2H, $2 \times \mathrm{H}-m-$ Phe-O), 7.47 (d, J= 2.1 Hz, 1H, H-4 Bf), 7.37 (d, J = 8.6 Hz, 1H, H-7 Bf), $7.22-7.14$ (m, 3H, H-6 Bf, $2 \times$ H-oPhe-O), 5.51 (d, $J=1.6 \mathrm{~Hz}, 1 \mathrm{H}, \mathrm{H}-1$ ), 4.04 (dd, J=3.4, $1.8 \mathrm{~Hz}, 1 \mathrm{H}, \mathrm{H}-2$ ), 3.88 (dd, J = 9.5, $3.5 \mathrm{~Hz}, 1 \mathrm{H}, \mathrm{H}-3$ ), $3.66(\mathrm{dq}, J=9.9,6.2 \mathrm{~Hz}, 1 \mathrm{H}, \mathrm{H}-5), 3.49(\mathrm{t}, J=9.5 \mathrm{~Hz}, 1 \mathrm{H}, \mathrm{H}-4), 2.35\left(\mathrm{~s}, 3 \mathrm{H}, \mathrm{CH}_{3} \mathrm{Bf}\right), 1.26(\mathrm{~d}, J=6.2 \mathrm{~Hz}, 4 \mathrm{H}$, $\mathrm{CH}_{3}$ Rha). ${ }^{13} \mathrm{C}$ NMR (101 MHz, CD $\mathrm{OD}$ ) $\delta 157.9$ (C quat.-Phe-O), 153.4 (C-7a Bf), 153.3 (C-2 Bf), 134.0 (C-5 Bf), 129.2 (2 x C-m-Phe-O), 126.2 (C-3a Bf, C quat.-Phe), 125.1 (C-6 Bf), 119.7 (C-4 Bf), 117.7 (2 x C-o-Phe- 
O), 112.7 (C-7 Bf), 111.0 (C-3 Bf), 99.7 (C-1), 73.8 (C-4), 72.2 (C-3), 72.0 (C-2), 70.8 (C-5), 18.1 ( $\mathrm{CH}_{3} \mathrm{Rha}$ ), $9.3\left(\mathrm{CH}_{3} \mathrm{Bf}\right)$. HRMS (ESI) calcd for $\mathrm{C}_{21} \mathrm{H}_{21} \mathrm{O}_{6} \mathrm{Cl}_{1} \mathrm{Na}_{1}[\mathrm{M}+\mathrm{Na}]^{+} 427.09189$, found 427.09208 .

\subsubsection{EZ-4-[3-methyl-5-(prop-1-enyl)benzofuran-2-yl]phenoyl $\alpha$-D-mannopyranoside (28a)}

Compound 28 a (34 mg, $0.08 \mathrm{mmol}$ ) was prepared following general procedures $4.2 .2(28,54 \%$ ) and 4.2.3 (quant.) and it was isolated as 1:1 E:Z mixture after automated flash chromatography (chloroform/methanol gradient elution). $R_{\mathrm{f}}=0.46\left(9: 1 \mathrm{CH}_{2} \mathrm{Cl}_{2}: \mathrm{CH}_{3} \mathrm{OH}\right) .{ }^{1} \mathrm{H} \mathrm{NMR}\left(400 \mathrm{MHz}, \mathrm{CD}_{3} \mathrm{OD}\right) \delta$ $7.78-7.69\left(\mathrm{~m}, 5 \mathrm{H}, 2 \times \mathrm{H}-\mathrm{m}\right.$-Phe-O), $7.44\left(\mathrm{~s}, 1 \mathrm{H}, \mathrm{H}-4 \mathrm{Bf}_{E}\right), 7.42\left(\mathrm{~s}, 1 \mathrm{H}, \mathrm{H}-4 \mathrm{Bf}_{z}\right), 7.39(\mathrm{~d}, J=8.5 \mathrm{~Hz}, 1 \mathrm{H}, \mathrm{H}-7$ $\left.\mathrm{Bf}_{Z}\right), 7.33\left(\mathrm{~d}, J=8.5 \mathrm{~Hz}, 1 \mathrm{H}, \mathrm{H}-7 \mathrm{Bf}_{E}\right), 7.30-7.15\left(\mathrm{~m}, 7 \mathrm{H}, \mathrm{H}-6 \mathrm{Bf}_{E}, \mathrm{H}-6 \mathrm{Bf}_{Z}, 2 \times \mathrm{H}-\mathrm{o}-\mathrm{Phe}-0\right), 6.61-6.44(\mathrm{~m}$, $\left.2 \mathrm{H},=\mathrm{CH}-\mathrm{Ar}_{\mathrm{Z}}=\mathrm{CH}-\mathrm{Ar}_{E}\right), 6.24\left(\mathrm{dq}, J=15.6,6.5 \mathrm{~Hz}, 1 \mathrm{H},=\mathrm{CH}-\mathrm{Me}_{E}\right), 5.77\left(\mathrm{dq}, J=11.6,7.1 \mathrm{~Hz}, 1 \mathrm{H},=\mathrm{CH}-\mathrm{Me}_{z}\right)$, 5.56 (bs, 2H, H-1), $4.07-4.00$ (m, 2H, H-2), 3.93 (dd, J=9.4, 3.3 Hz, 2H, H-3), $3.84-3.69(\mathrm{~m}, 7 \mathrm{H}, \mathrm{H}-4, \mathrm{H}-$ 6a, H-6b), 3.62 (ddd, $J=9.7,5.0,2.5 \mathrm{~Hz}, 3 \mathrm{H}, \mathrm{H}-5), 2.42\left(\mathrm{~s}, 3 \mathrm{H}, \mathrm{CH}_{3} \mathrm{Bf}_{z}\right), 2.41\left(\mathrm{~s}, 4 \mathrm{H}, \mathrm{CH}_{3} \mathrm{Bf}_{E}\right), 1.92(\mathrm{dd}, J=$ $\left.7.2,1.8 \mathrm{~Hz}, 3 \mathrm{H}, \mathrm{CH}_{3}-\mathrm{CH}={ }_{z}\right), 1.88\left(\mathrm{dd}, J=6.6,1.5 \mathrm{~Hz}, 3 \mathrm{H}, \mathrm{CH}_{3}-\mathrm{CH}={ }_{E}\right) .{ }^{13} \mathrm{C} \mathrm{NMR}\left(101 \mathrm{MHz}, \mathrm{CD}_{3} \mathrm{OD}\right) \delta 157.7$

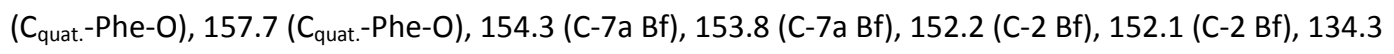
(C-5 Bf), 133.6 (C-5 Bf), 132.6 (C-3a Bf), 132.5 (=CH-Ar ${ }_{E}$ ), 132.4 (C-3a Bf), 131.3 (=CH-Ar $\left.z\right), 129.0$ (2 x C-

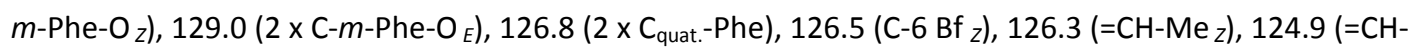
$\left.\mathrm{Me}_{E}\right), 123.4\left(\mathrm{C}-6 \mathrm{Bf}_{E}\right), 120.2\left(\mathrm{C}-4 \mathrm{Bf}_{Z}\right), 117.9$ (4 x C-o-Phe-O), 117.3 (C-4 Bf $\left.{ }_{E}\right), 111.5\left(\mathrm{C}-7 \mathrm{Bf}_{E}\right), 111.3(\mathrm{C}-3$ Bf), 111.2 (C-3 Bf), 111.1 (C-7 Bf Z, 100.1 (C-1), 75.5 (C-5), 72.4 (C-3), 71.9 (C-2), 68.3 (C-4), 62.7 (C-6), 18.6 $\left(\mathrm{CH}_{3}-\mathrm{CH}={ }_{E}\right), 14.8\left(\mathrm{CH}_{3}-\mathrm{CH}={ }_{2}\right), 9.4\left(2 \times \mathrm{CH}_{3} \mathrm{Bf}\right)$. HRMS (ESI) calcd for $\mathrm{C}_{24} \mathrm{H}_{26} \mathrm{O}_{7} \mathrm{Na}_{1}[\mathrm{M}+\mathrm{Na}]^{+}$ 449.15707, found 449.15713.

4.3.12 EZ-4-[3-methyl-5-(prop-1-enyl)benzofuran-2-yl]phenyl $\alpha$-L-rhamnopyranoside (29a) Compound 29a (29 mg, $0.07 \mathrm{mmol}$ ) was prepared following general procedures $4.2 .2(29,55 \%)$ and 4.2 .3 (quant.) and it was isolated as 1.5:1 E:Z mixture after automated flash chromatography (chloroform/methanol gradient elution). $R_{\mathrm{f}}=0.50\left(9: 1 \mathrm{CH}_{2} \mathrm{Cl}_{2}: \mathrm{CH}_{3} \mathrm{OH}\right) ;{ }^{1} \mathrm{H} \mathrm{NMR}\left(400 \mathrm{MHz}, \mathrm{CD}_{3} \mathrm{OD}\right) \delta 7.77-7.67(\mathrm{~m}, 5 \mathrm{H}, 2 \times \mathrm{H}-$ $m$-Phe-O), 7.43 (bs, $1 \mathrm{H}, \mathrm{H}-4 \mathrm{Bf}_{E}$ ), 7.40 (bs, $\left.1 \mathrm{H}, \mathrm{H}-4 \mathrm{Bf}_{Z}\right), 7.38\left(\mathrm{bd}, J=8.4 \mathrm{~Hz}, 1 \mathrm{H}, \mathrm{H}-7 \mathrm{Bf}_{Z}\right), 7.32(\mathrm{bd}, J=8.5$ $\left.\mathrm{Hz}, 2 \mathrm{H}, \mathrm{H}-7 \mathrm{Bf}_{E}\right), 7.27\left(\mathrm{dd}, J=8.6,1.4 \mathrm{~Hz}, 2 \mathrm{H}, \mathrm{H}-6 \mathrm{Bf}_{E}\right), 7.24-7.09\left(\mathrm{~m}, 7 \mathrm{H}, \mathrm{H}-6 \mathrm{Bf}_{Z}, 2 \times \mathrm{H}-0-\mathrm{Phe}-0\right), 6.62-$ $6.40\left(\mathrm{~m}, 2 \mathrm{H},=\mathrm{CH}-\mathrm{Ar}_{\mathrm{z}}=\mathrm{CH}-\mathrm{Ar}_{E}\right), 6.23\left(\mathrm{dq}, J=15.5,6.5 \mathrm{~Hz}, 2 \mathrm{H},=\mathrm{CH}-\mathrm{Me}_{E}\right), 5.77(\mathrm{dq}, J=11.6,7.1 \mathrm{~Hz}, 1 \mathrm{H}$, $=\mathrm{CH}-\mathrm{Me}_{z}$ ), 5.51 (bs, 3H, H-1), 4.02 (dd, J=15.9, 3.8 Hz, 3H, H-2), 3.88 (dd, J=9.5, 3.3 Hz, 3H, H-3), $3.76-$ $3.56(\mathrm{~m}, 3 \mathrm{H}, \mathrm{H}-5), 3.49(\mathrm{t}, J=9.5 \mathrm{~Hz}, 3 \mathrm{H}, \mathrm{H}-4), 2.40\left(\mathrm{~s}, 3 \mathrm{H}, \mathrm{CH}_{3} \mathrm{Bf}_{\mathrm{z}}\right), 2.39$ (s, $4 \mathrm{H}, \mathrm{CH}_{3} \mathrm{Bf}_{E}$ ), 1.91 (dd, J = 7.2, $1.7 \mathrm{~Hz}, 3 \mathrm{H}, \mathrm{CH}_{3}-\mathrm{CH}=\mathrm{z}$ ), 1.88 (dd, J=6.5, $1.3 \mathrm{~Hz}, 4 \mathrm{H}, \mathrm{CH}_{3}-\mathrm{CH}={ }_{E}$ ), 1.26 (d, J=6.1 Hz, $11 \mathrm{H}, \mathrm{CH}_{3} \mathrm{Rha}$ ). ${ }^{13} \mathrm{C}$ NMR (101 MHz, CD ${ }_{3} \mathrm{OD}$ ) $\delta 157.6$ (2 x Cquat.-Phe-O), 154.3 (C-7a Bf), 153.8 (C-7a Bf), 152.1 (2 x C-2 Bf), 134.2 (C-5 Bf), 133.5 (C-5 Bf), 132.6 (=CH-Ar ${ }_{E}$ ), 132.6 (C-3a Bf), 132.4 (C-3a Bf), 131.4 (=CH-Ar z), 129.0 (4 x C-m-Phe-O), 126.7 ( 2 x C quat.-Phe), $126.5\left(\mathrm{C}-6 \mathrm{Bf}_{Z}\right), 126.3\left(=\mathrm{CH}-\mathrm{Me}_{z}\right), 124.8\left(=\mathrm{CH}-\mathrm{Me}_{E}\right), 123.4\left(\mathrm{C}-6 \mathrm{Bf}_{E}\right)$, 120.2 (C-4 Bf 2$), 117.7(4 \times \mathrm{C}-0-\mathrm{Phe}-0), 117.3\left(\mathrm{C}-4 \mathrm{Bf}_{E}\right), 111.4\left(\mathrm{C}-7 \mathrm{Bf}_{E}\right), 111.1\left(\mathrm{C}-7 \mathrm{Bf}_{Z}\right), 99.8(\mathrm{C}-1), 73.8$ 
(C-4), 72.2 (C-3), 72.0 (C-2), $70.8(\mathrm{C}-5), 18.6\left(\mathrm{CH}_{3}-\mathrm{CH}={ }_{E}\right), 14.8\left(\mathrm{CH}_{3}-\mathrm{CH}={ }_{z}\right), 9.4\left(2 \times \mathrm{CH}_{3} \mathrm{Bf}\right)$. ESI-MS calcd for $\mathrm{C}_{24} \mathrm{H}_{26} \mathrm{O}_{6} \mathrm{Na}_{1}[\mathrm{M}+\mathrm{Na}]^{+} 433.2$, found 433.5; calcd for $\mathrm{C}_{48} \mathrm{H}_{51} \mathrm{O}_{12}[2 \mathrm{M}-\mathrm{H}]^{-} 819.3$, found 819.9.

4.3.13 EZ-4-[3-methyl-5-(prop-1-enyl)benzofuran-2-yl]phenyl $\beta$-D-glucopyranoside (30a) Compound 30a (12 mg, $0.02 \mathrm{mmol}$ ) was prepared following general procedures 4.2 .1 (30, 39\%, yield based on the limiting agent) and 4.2.3 (>95\%) and it was isolated as 3:1 E:Z mixture by a flash chromatography $\left(\mathrm{CHCl}_{3}\right.$ : $\mathrm{MeOH}$ ) followed by a reverse-phase chromatography (water/methanol) that allowed to remove donor derived by-products. $R_{\mathrm{f}}=0.25\left(9: 1 \mathrm{CH}_{2} \mathrm{Cl}_{2}: \mathrm{CH}_{3} \mathrm{OH}\right) .{ }^{1} \mathrm{H} \mathrm{NMR}\left(400 \mathrm{MHz}, \mathrm{CD}_{3} \mathrm{OD}\right) \delta 7.80-7.68(\mathrm{~m}, 8 \mathrm{H}, 2 \mathrm{x}$ H-m-Phe-O), $7.48-7.44\left(\mathrm{~m}, 3 \mathrm{H}, \mathrm{H}-4 \mathrm{Bf}_{E}\right), 7.44-7.42\left(\mathrm{~m}, 1 \mathrm{H}, \mathrm{H}-4 \mathrm{Bf}_{z}\right), 7.40\left(\mathrm{~d}, J=8.5 \mathrm{~Hz}, 1 \mathrm{H}, \mathrm{H}-7 \mathrm{Bf}_{z}\right)$, $7.34\left(\mathrm{~d}, J=8.5 \mathrm{~Hz}, 3 \mathrm{H}, \mathrm{H}-7 \mathrm{Bf}_{E}\right), 7.29\left(\mathrm{dd}, J=8.5,1.5 \mathrm{~Hz}, 3 \mathrm{H}, \mathrm{H}-6 \mathrm{Bf}_{E}\right), 7.26-7.19\left(\mathrm{~m}, 10 \mathrm{H}, \mathrm{H}-6 \mathrm{Bf}_{Z}, 2 \times \mathrm{H}-\right.$ o-Phe-O), $6.59-6.47\left(\mathrm{~m}, 4 \mathrm{H},=\mathrm{CH}-\mathrm{Ar}_{z}=\mathrm{CH}-\mathrm{Ar}_{E}\right), 6.25\left(\mathrm{dq}, J=15.7,6.6 \mathrm{~Hz}, 3 \mathrm{H},=\mathrm{CH}-\mathrm{Me}_{E}\right), 5.78(\mathrm{dq}, J=$ 11.5, 7.2 Hz, 1H, =CH-Me ), 4.99 (dd, $J=5.4,2.0 \mathrm{~Hz}, 4 \mathrm{H}, \mathrm{H}-1$ ), 3.93 (dd, $J=12.1,1.9 \mathrm{~Hz}, 5 \mathrm{H}, \mathrm{H}-6 \mathrm{a}$ ), 3.73 (dd, $J=12.1,5.6 \mathrm{~Hz}, 5 \mathrm{H}, \mathrm{H}-6 \mathrm{~b}), 3.54-3.45(\mathrm{~m}, 14 \mathrm{H}, \mathrm{H}-5, \mathrm{H}-2, \mathrm{H}-3), 3.45-3.38(\mathrm{~m}, 4 \mathrm{H}, \mathrm{H}-4), 2.43(\mathrm{~s}, J=$ $\left.4.3 \mathrm{~Hz}, 3 \mathrm{H}, \mathrm{CH}_{3} \mathrm{Bf}_{2}\right), 2.42\left(\mathrm{~s}, 9 \mathrm{H}, \mathrm{CH}_{3} \mathrm{Bf}_{E}\right), 1.93$ (dd, J = 7.2, $1.8 \mathrm{~Hz}, 3 \mathrm{H}, \mathrm{CH}_{3}-\mathrm{CH}=z$ ), 1.89 (dd, J = 6.6, 1.5 $\left.\mathrm{Hz}, 10 \mathrm{H}, \mathrm{CH}_{3}-\mathrm{CH}={ }_{E}\right) .{ }^{13} \mathrm{C} \mathrm{NMR}\left(101 \mathrm{MHz}, \mathrm{CD}_{3} \mathrm{OD}\right) \delta 158.9$ (C quat. $_{\text {Phe-O) }} 158.8$ (C quat. - Phe-O), 154.3 (C-7a Bf), 153.8 (C-7a Bf), 152.2 (2 x C-2 Bf), 134.3 (C-5 Bf), 133.6 (C-5 Bf), 132.6 (=CH-Ar $\left.{ }_{E}\right), 131.3$ (=CH-Ar ${ }_{2}$ ), 129.0 ( 2 x C-m-Phe-O z), 128.9 ( 2 x C-m-Phe-O $E$ ), 126.8 (C-3a Bf), 126.5 (C-6 Bf z), 126.3 (=CH-Me $z$ ), 124.9 $\left(=\mathrm{CH}-\mathrm{Me}_{E}\right), 123.4\left(\mathrm{C}-6 \mathrm{Bf}_{E}\right), 120.2(\mathrm{C}-4 \mathrm{Bf} Z), 117.9$ (4 x C-o-Phe-O), $117.3\left(\mathrm{C}-4 \mathrm{Bf}_{E}\right), 111.4\left(\mathrm{C}-7 \mathrm{Bf}_{E}\right), 111.2$ (C-3 Bf), 111.1 (C-7 Bf $\left.{ }_{Z}\right), 102.1$ (C-1), 78.2 (C-5), 78.0 (C-3), 74.9 (C-2), 71.4 (C-4), 62.5 (C-6), $18.6\left(\mathrm{CH}_{3^{-}}\right.$ $\left.\mathrm{CH}={ }_{E}\right), 14.8\left(\mathrm{CH}_{3}-\mathrm{CH}={ }_{z}\right), 9.4\left(2 \times \mathrm{CH}_{3} \mathrm{Bf}\right)$. HRMS (ESI) calcd for $\mathrm{C}_{24} \mathrm{H}_{26} \mathrm{O}_{7} \mathrm{Na}_{1}[\mathrm{M}+\mathrm{Na}]^{+}$449.15707, found 449.15714.

\subsubsection{EZ-4-[3-methyl-5-(prop-1-enyl)benzofuran-2-yl]phenyl $\beta$-L-glucopyranoside (31a) Compound}

$31 \mathrm{a}$ (35 $\mathrm{mg}, 0.08 \mathrm{mmol}$ ) was prepared following general procedures 4.2 .1 and 4.2 .3 and it was isolated as 1.7:1 E:Z mixture in $38 \%$ yield (based on the limiting agent) over two steps. $R_{\mathrm{f}}=0.25$ (9:1 $\mathrm{CH}_{2} \mathrm{Cl}_{2}: \mathrm{CH}_{3} \mathrm{OH}$ ). ${ }^{1} \mathrm{H}$ NMR (400 MHz, CD $\left.{ }_{3} \mathrm{OD}\right) \delta 7.79-7.67$ (m, 6H, $\left.2 \times \mathrm{H}-m-\mathrm{Phe}-\mathrm{O}\right), 7.45$ (s, 2H, H-4 Bf $\mathrm{E}_{\mathrm{E}}$ ), $7.43\left(\mathrm{~s}, 1 \mathrm{H}, \mathrm{H}-4 \mathrm{Bf}_{z}\right), 7.39\left(\mathrm{~d}, J=8.4 \mathrm{~Hz}, 1 \mathrm{H}, \mathrm{H}-7 \mathrm{Bf}_{z}\right), 7.34\left(\mathrm{~d}, J=8.5 \mathrm{~Hz}, 2 \mathrm{H}, \mathrm{H}-7 \mathrm{Bf}_{E}\right), 7.28(\mathrm{dd}, J=8.5,1.6$ $\left.\mathrm{Hz}, 2 \mathrm{H}, \mathrm{H}-6 \mathrm{Bf}_{E}\right), 7.26-7.19\left(\mathrm{~m}, 7 \mathrm{H}, \mathrm{H}-6 \mathrm{Bf}_{Z}, 2 \times \mathrm{H}-0-\mathrm{Phe}-\mathrm{O}\right), 6.61-6.44\left(\mathrm{~m}, 3 \mathrm{H},=\mathrm{CH}-\mathrm{Ar}_{Z}=\mathrm{CH}-\mathrm{Ar}_{E}\right), 6.24$ (dq, $\left.J=15.6,6.5 \mathrm{~Hz}, 2 \mathrm{H},=\mathrm{CH}-\mathrm{Me}_{E}\right), 5.77\left(\mathrm{dq}, J=11.6,7.2 \mathrm{~Hz}, 1 \mathrm{H},=\mathrm{CH}-\mathrm{Me}_{z}\right), 5.03-4.95(\mathrm{~m}, 3 \mathrm{H}, \mathrm{H}-1)$, $3.93(\mathrm{dd}, J=11.9,1.7 \mathrm{~Hz}, 3 \mathrm{H}, \mathrm{H}-6 \mathrm{a}), 3.73$ (dd, $J=12.1,5.5 \mathrm{~Hz}, 3 \mathrm{H}, \mathrm{H}-6 \mathrm{~b}), 3.57-3.38(\mathrm{~m}, 13 \mathrm{H}, \mathrm{H}-5, \mathrm{H}-2, \mathrm{H}-$ 3, $\mathrm{H}-4), 2.43\left(\mathrm{~d}, J=5.4 \mathrm{~Hz}, 3 \mathrm{H}, \mathrm{CH}_{3} \mathrm{Bf}_{z}\right), 2.42\left(\mathrm{~s}, 6 \mathrm{H}, \mathrm{CH}_{3} \mathrm{Bf}_{E}\right), 1.92\left(\mathrm{dd}, J=7.2,1.8 \mathrm{~Hz}, 3 \mathrm{H}, \mathrm{CH}_{3}-\mathrm{CH}_{z}\right)$, 1.89 (dd, $J=6.6,1.5 \mathrm{~Hz}, 6 \mathrm{H}, \mathrm{CH}_{3}-\mathrm{CH}={ }_{E}$ ). ESI-MS calcd for $\mathrm{C}_{24} \mathrm{H}_{26} \mathrm{O}_{7} \mathrm{Na}_{1}[\mathrm{M}+\mathrm{Na}]^{+}$449.2, found 449.4; calcd for $\mathrm{C}_{48} \mathrm{H}_{52} \mathrm{O}_{14} \mathrm{Na}_{1}[2 \mathrm{M}+\mathrm{Na}]^{+} 875.3$, found 875.2.

4.3.15 EZ-4-[3-methyl-5-(prop-1-enyl)benzofuran-2-yl]phenyl $\beta$-D-galactopyranoside (32a) Compound 32a (21 mg, $0.049 \mathrm{mmol}$ ) was prepared following general procedures 4.2 .1 and 4.2.3 and it was isolated 
as 1.7:1 E:Z mixture in 70\% yield (based on the limiting agent) over two steps. $R_{\mathrm{f}}=0.25$ (9:1

$\mathrm{CH}_{2} \mathrm{Cl}_{2}: \mathrm{CH}_{3} \mathrm{OH}$ ). ${ }^{1} \mathrm{H}$ NMR (400 MHz, $\left.\mathrm{CD}_{3} \mathrm{OD}\right) \delta 7.78-7.66$ (m, 5H, $\left.2 \times \mathrm{H}-m-\mathrm{Phe}-\mathrm{O}\right), 7.44$ (d, J = 11.8 Hz, $\left.3 \mathrm{H}, \mathrm{H}-4 \mathrm{Bf}_{E}\right), 7.43\left(\mathrm{bs}, 1 \mathrm{H}, \mathrm{H}-4 \mathrm{Bf}_{Z}\right), 7.40\left(\mathrm{~d}, J=8.4 \mathrm{~Hz}, 1 \mathrm{H}, \mathrm{H}-7 \mathrm{Bf}_{Z}\right), 7.34\left(\mathrm{~d}, J=8.5 \mathrm{~Hz}, 3 \mathrm{H}, \mathrm{H}-7 \mathrm{Bf}_{E}\right), 7.29$ $\left(\mathrm{dd}, J=8.5,1.5 \mathrm{~Hz}, 3 \mathrm{H}, \mathrm{H}-6 \mathrm{Bf}_{E}\right), 7.27-7.16\left(\mathrm{~m}, 7 \mathrm{H}, \mathrm{H}-6 \mathrm{Bf}_{z}, 2 \times \mathrm{H}-0-\mathrm{Phe}-\mathrm{O}\right), 6.62-6.43\left(\mathrm{~m}, 4 \mathrm{H},=\mathrm{CH}-\mathrm{Ar}_{z}\right.$, $\left.=\mathrm{CH}-\mathrm{Ar}_{E}\right), 6.25\left(\mathrm{dq}, J=15.7,6.5 \mathrm{~Hz}, 3 \mathrm{H},=\mathrm{CH}-\mathrm{Me}_{E}\right), 5.78\left(\mathrm{dq}, J=11.6,7.1 \mathrm{~Hz}, 1 \mathrm{H},=\mathrm{CH}-\mathrm{Me}_{z}\right), 4.95(\mathrm{dd}, J=$ 7.7, $1.7 \mathrm{~Hz}, 3 \mathrm{H}, \mathrm{H}-1$ ), 3.93 (d, $J=3.3 \mathrm{~Hz}, 3 \mathrm{H}, \mathrm{H}-4), 3.90-3.69(\mathrm{~m}, 12 \mathrm{H}, \mathrm{H}-2, \mathrm{H}-6 \mathrm{a}, \mathrm{H}-6 \mathrm{~b}, \mathrm{H}-5), 3.61$ (dd, $J=$ 9.7, 3.3 Hz, 3H, H-3), $2.43\left(\mathrm{~s}, 3 \mathrm{H}, \mathrm{CH}_{3} \mathrm{Bf}_{z}\right), 2.42\left(\mathrm{~s}, 5 \mathrm{H}, \mathrm{CH}_{3} \mathrm{Bf}_{E}\right), 1.92\left(\mathrm{dd}, J=7.2,1.8 \mathrm{~Hz}, 3 \mathrm{H}, \mathrm{CH}_{3}-\mathrm{CH}=z\right.$ ), 1.89 (dd, $J=6.5,1.5 \mathrm{~Hz}, 5 \mathrm{H}, \mathrm{CH}_{3}-\mathrm{CH}={ }_{E}$ ). ${ }^{13} \mathrm{C} \mathrm{NMR}\left(101 \mathrm{MHz}, \mathrm{CD}_{3} \mathrm{OD}\right) \delta 159.0$ (C quat. - Phe-O), 154.3 (C-7a Bf), 152.2 (C-2 Bf), 134.3 (C-5 Bf), 132.7 (C-3a Bf), 132.6 (=CH-Ar ${ }_{E}$ ), 131.3 (=CH-Ar $z$ ), 129.0 (2 x C-m-Phe-

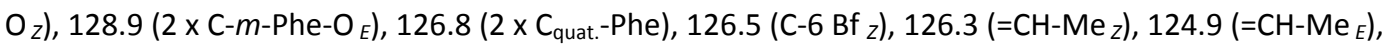
123.4 (C-6 Bf $\left.E_{E}\right), 120.2\left(\mathrm{C}-4 \mathrm{Bf}_{Z}\right), 118.0$ (4 x C-o-Phe-O), $117.3\left(\mathrm{C}-4 \mathrm{Bf}_{E}\right), 111.4\left(\mathrm{C}-7 \mathrm{Bf}_{E}\right), 111.2(2 \times \mathrm{C}-3 \mathrm{Bf})$, $111.1\left(\mathrm{C}-7 \mathrm{Bf}_{Z}\right), 102.8$ (C-1), 77.1 (C-5), 74.9 (C-3), 72.3 (C-2), 70.2 (C-4), 62.5 (C-6), $18.6\left(\mathrm{CH}_{3}-\mathrm{CH}={ }_{E}\right)$, 14.8, $\left(\mathrm{CH}_{3}-\mathrm{CH}={ }_{z}\right), 9.4\left(2 \times \mathrm{CH}_{3} \mathrm{Bf}\right)$. HRMS (ESI) calcd for $\mathrm{C}_{24} \mathrm{H}_{26} \mathrm{O}_{7} \mathrm{Na}_{1}[\mathrm{M}+\mathrm{Na}]^{+} 449.15707$, found 449.15756.

4.3.16 EZ-4-[3-methyl-5-(prop-1-enyl)benzofuran-2-yl]phenyl $\beta$-L-galactopyranoside (33a) Compound $33 a$ (36 $\mathrm{mg}, 0.08 \mathrm{mmol}$ ) was prepared following general procedures $4.2 .1(33,71 \%$, yield based on the limiting agent) and 4.2.3 (>95\%) and it was isolated as 1.4:1 E:Z mixture. $R_{\mathrm{f}}=0.25\left(9: 1 \mathrm{CH}_{2} \mathrm{Cl}_{2}: \mathrm{CH}_{3} \mathrm{OH}\right)$. ${ }^{1} \mathrm{H}$ NMR (400 MHz, CD $\left.3 \mathrm{OD}\right) \delta 7.79-7.69$ (m, 5H, $2 \times \mathrm{H}-m$-Phe-O), 7.46 (bs, 2H, H-4 Bf ${ }_{E}$ ), 7.43 (bs, $1 \mathrm{H}, \mathrm{H}-4$ $\left.\mathrm{Bf}_{z}\right), 7.40\left(\mathrm{~d}, J=8.4 \mathrm{~Hz}, 1 \mathrm{H}, \mathrm{H}-7 \mathrm{Bf}_{z}\right), 7.34\left(\mathrm{~d}, J=8.5 \mathrm{~Hz}, 2 \mathrm{H}, \mathrm{H}-7 \mathrm{Bf}_{E}\right), 7.29$ (dd, J = 8.5, $1.4 \mathrm{~Hz}, 2 \mathrm{H}, \mathrm{H}-6 \mathrm{Bf}$ E), $7.27-7.15\left(\mathrm{~m}, 5 \mathrm{H}, \mathrm{H}-6 \mathrm{Bf}_{Z}, 2 \times \mathrm{H}-o-\mathrm{Phe}-0\right), 6.62-6.43\left(\mathrm{~m}, 3 \mathrm{H},=\mathrm{CH}-\mathrm{Ar}_{\mathrm{Z}}=\mathrm{CH}-\mathrm{Ar}_{E}\right), 6.25(\mathrm{dq}, J=13.2$, $\left.6.5 \mathrm{~Hz}, 2 \mathrm{H},=\mathrm{CH}-\mathrm{Me}_{E}\right), 5.78\left(\mathrm{dq}, J=11.6,7.1 \mathrm{~Hz}, 1 \mathrm{H},=\mathrm{CH}-\mathrm{Me}_{z}\right), 4.95$ (dd, J = 7.7, 1.6 Hz, 3H, H-1), 3.93 (d, $J=3.3 \mathrm{~Hz}, 3 \mathrm{H}, \mathrm{H}-4), 3.89-3.68(\mathrm{~m}, 12 \mathrm{H}, \mathrm{H}-2, \mathrm{H}-6 \mathrm{a}, \mathrm{H}-6 \mathrm{~b}, \mathrm{H}-5), 3.61$ (dd, J=9.7, $3.3 \mathrm{~Hz}, 3 \mathrm{H}, \mathrm{H}-3), 2.43$ (s, $3 \mathrm{H}, \mathrm{CH}_{3} \mathrm{Bf}_{z}$ ), $2.42\left(\mathrm{~s}, 5 \mathrm{H}, \mathrm{CH}_{3} \mathrm{Bf}_{E}\right.$ ), 1.92 (dd, $\left.J=7.2,1.7 \mathrm{~Hz}, 3 \mathrm{H}, \mathrm{CH}_{3}-\mathrm{CH}={ }_{z}\right), 1.89$ (dd, $J=6.5,1.4 \mathrm{~Hz}, 5 \mathrm{H}$, $\mathrm{CH}_{3}-\mathrm{CH}={ }_{E}$ ). ESI-MS calcd for $\mathrm{C}_{24} \mathrm{H}_{26} \mathrm{O}_{7} \mathrm{Na}_{1}[\mathrm{M}+\mathrm{Na}]^{+} 449.2$, found 449.5; calcd for $\mathrm{C}_{48} \mathrm{H}_{52} \mathrm{O}_{14} \mathrm{Na}_{1}[2 \mathrm{M}+\mathrm{Na}]^{+}$ 875.3, found 875.3; calcd for $\mathrm{C}_{48} \mathrm{H}_{51} \mathrm{O}_{14}[2 \mathrm{M}-\mathrm{H}]^{-} 851.3$, found 851.3.

4.3.17 EZ-4-[3-methyl-5-(prop-1-enyl)benzofuran-2-yl]phenyl $\beta$-L-fucopyranoside (34a) Compound $34 \mathrm{a}(17 \mathrm{mg}, 0.043 \mathrm{mmol}$ ) was prepared following general procedures 4.2 .1 and 4.2 .3 and it was isolated as 3.5:1 E:Z mixture in $49 \%$ yield over two steps. $R_{\mathrm{f}}=0.37\left(9: 1 \mathrm{CH}_{2} \mathrm{Cl}_{2}: \mathrm{CH}_{3} \mathrm{OH}\right) .{ }^{1} \mathrm{H} \mathrm{NMR}(400 \mathrm{MHz}$, $\mathrm{CD}_{3} \mathrm{OD}$ ) $\delta 7.76-7.67\left(\mathrm{~m}, 10 \mathrm{H}, 2 \times \mathrm{H}-\mathrm{m}\right.$-Phe-O), 7.44 (bs, 4H, H-4 Bf $\left.{ }_{E}\right), 7.41$ (bs, $\left.1 \mathrm{H}, \mathrm{H}-4 \mathrm{Bf}_{Z}\right), 7.39(\mathrm{~d}, J=$ $\left.8.4 \mathrm{~Hz}, 1 \mathrm{H}, \mathrm{H}-7 \mathrm{Bf}_{Z}\right), 7.33\left(\mathrm{~d}, J=8.5 \mathrm{~Hz}, 4 \mathrm{H}, \mathrm{H}-7 \mathrm{Bf}_{E}\right), 7.30-7.25\left(\mathrm{~m}, 4 \mathrm{H}, \mathrm{H}-6 \mathrm{Bf}_{E}\right), 7.22-7.11(\mathrm{~m}, 13 \mathrm{H}, \mathrm{H}-$ $\left.6 \mathrm{Bf}_{z}, 2 \times \mathrm{H}-o-\mathrm{Phe}-\mathrm{O}\right), 6.59-6.42\left(\mathrm{~m}, 5 \mathrm{H},=\mathrm{CH}-\mathrm{Ar}_{z}=\mathrm{CH}-\mathrm{Ar}_{E}\right), 6.24\left(\mathrm{dq}, J=15.6,6.5 \mathrm{~Hz}, 4 \mathrm{H},=\mathrm{CH}-\mathrm{Me}_{E}\right)$, $5.77\left(\mathrm{dq}, J=11.6,7.2 \mathrm{~Hz}, 1 \mathrm{H},=\mathrm{CH}-\mathrm{Me}_{z}\right), 4.92(\mathrm{dd}, J=7.7,2.3 \mathrm{~Hz}, 6 \mathrm{H}, \mathrm{H}-1), 3.89-3.74(\mathrm{~m}, 11 \mathrm{H}, \mathrm{H}-5, \mathrm{H}-2)$, $3.68(\mathrm{~d}, J=3.1 \mathrm{~Hz}, 6 \mathrm{H}, \mathrm{H}-4), 3.60(\mathrm{dd}, J=9.7,3.4 \mathrm{~Hz}, 6 \mathrm{H}, \mathrm{H}-3), 2.41\left(\mathrm{~s}, 4 \mathrm{H}, \mathrm{CH}_{3} \mathrm{Bf}_{z}\right), 2.40\left(\mathrm{~s}, 10 \mathrm{H}, \mathrm{CH}_{3} \mathrm{Bf}_{E}\right)$, 
$1.92\left(\mathrm{dd}, J=7.2,1.8 \mathrm{~Hz}, 3 \mathrm{H}, \mathrm{CH}_{3}-\mathrm{CH}=\mathrm{z}\right), 1.88$ (dd, J=6.6, $\left.1.5 \mathrm{~Hz}, 11 \mathrm{H}, \mathrm{CH}_{3}-\mathrm{CH}={ }_{E}\right), 1.32(\mathrm{~d}, J=6.5 \mathrm{~Hz}, 18 \mathrm{H}$,

$\mathrm{CH}_{3}$ Fuc). ${ }^{13} \mathrm{C}$ NMR (101 MHz, CD $\mathrm{OD}$ ) $\delta 158.9$ (C quat. - Phe-O), 158.8 (C quat.-Phe-O), 154.3 (C-7a Bf), 153.8 (C-7a Bf), 152.2 (C-2 Bf), 152.1 (C-2 Bf), 134.3 (C-5 Bf), 133.6 (C-5 Bf), 132.7 (C-3a Bf), , 132.6 (=CH-Ar E),

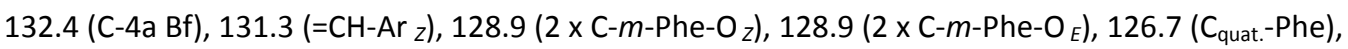
126.6 ( $\mathrm{C}_{\text {quat. }}$-Phe), $126.5\left(\mathrm{C}-6 \mathrm{Bf}_{Z}\right), 126.3$ (=CH-Me $), 124.9\left(=\mathrm{CH}-\mathrm{Me}_{E}\right), 123.4\left(\mathrm{C}-6 \mathrm{Bf}_{E}\right), 120.2\left(\mathrm{C}-4 \mathrm{Bf}_{z}\right)$, 117.8 (4 x C-o-Phe-O), $117.3\left(\mathrm{C}-4 \mathrm{Bf}_{E}\right), 111.4$ (C-7 Bf ${ }_{E}$ ), 111.2 (C-3 Bf), 111.1 (C-3 Bf), 111.1 (C-7 Bf ${ }_{Z}$ ), 102.4 (C-1), 75.0 (C-3), 72. 9 (C-4), 72.2 (C-5), 72.0 (C-2), $18.6\left(\mathrm{CH}_{3}-\mathrm{CH}={ }_{E}\right), 16.8\left(2 \times \mathrm{CH}_{3} \mathrm{FuC}\right), 14.8\left(\mathrm{CH}_{3}-\right.$ $\left.\mathrm{CH}={ }_{2}\right), 9.4\left(2 \times \mathrm{CH}_{3} \mathrm{Bf}\right)$. HRMS (ESI) calcd for $\mathrm{C}_{24} \mathrm{H}_{26} \mathrm{O}_{6} \mathrm{Na}_{1}[\mathrm{M}+\mathrm{Na}]^{+} 433.16216$, found 433.16227 .

\section{Acknowledgments}

This work was supported by Premio Fondazione Cariplo - Ricerca di frontiera 2011 (Project: Chemical control of signaling pathways by modulation of hub proteins, CheCOSP). We thank Dr. Anna Daghetti for technical help with MS analysis. The HRMS spectra have been obtained from CIGA (Centro Interdipartimentale Grandi Apparecchiature, Università degli Studi di Milano).

\section{Supplementary data}

Supplementary data associated with this article (synthesis and characterization of all protected glycosides, ${ }^{1} \mathrm{H}-\mathrm{NMR}$ and ${ }^{13} \mathrm{C}$-NMR spectra of all final compounds) can be found, in the online version, at http://dx.doi.org/10.1016/ 


\section{References}

1. Trepel, J.; Mollapour, M.; Giaccone, G.; Neckers, L. Nature reviews. Cancer 2010, 10, 537-549.

2. Jhaveri, K.; Taldone, T.; Modi, S.; Chiosis, G. Biochimica et biophysica acta 2012, 1823, $742-755$.

3. Pearl, L. H.; Prodromou, C. Curr. Opin. Struct. Biol. 2000, 10, 46-51.

4. Li, J.; Soroka, J.; Buchner, J. Biochimica et biophysica acta 2012, 1823, 624-635.

5. Taldone, T.; Gozman, A.; Maharaj, R.; Chiosis, G. Curr. Opin. Pharmacol. 2008, 8, 370-374.

6. Kitson, R. R. A.; Moody, C. J. J. Org. Chem. 2013, 78, 5117-5141.

7. Yu, X. M.; Shen, G.; Neckers, L.; Blake, H.; Holzbeierlein, J.; Cronk, B.; Blagg, B. S. J. J. Am. Chem. Soc. 2005, $127,12778-12779$.

8. Burlison, J. A.; Avila, C.; Vielhauer, G.; Lubbers, D. J.; Holzbeierlein, J.; Blagg, B. S. J. J. Org. Chem. 2008, 73, 2130-2137.

9. Patel, S. M.; Fuente, M. d. I.; Ke, S.; Guimaraes, A. M. R.; Oliyide, A. O.; Ji, X.; Stapleton, P.; Osbourn, A.; Pan, Y.; Bowles, D. J.; Davis, B. G.; Schatzlein, A.; Yang, M. Chem. Commun. 2011, 47, 10569-10571.

10. Morra, G.; Verkhivker, G.; Colombo, G. PLoS Comput Biol 2009, 5, e1000323.

11. Morra, G.; Neves, M. A. C.; Plescia, C. J.; Tsustsumi, S.; Neckers, L.; Verkhivker, G.; Altieri, D. C.; Colombo,

G. J. Chem. Theory Comput. 2010, 6, 2978-2989.

12. Bowden, B.; Ritchie, E.; Taylor, W. Aust. J. Chem 1972, 25, 2659-2669.

Eidamshaus, C.; Burch, J. D. Org. Lett. 2008, 10, 4211-4214.

Miyata, O.; Takeda, N.; Naito, T. Org. Lett. 2004, 6, 1761-1763.

Bach, T.; Bartels, M. Synthesis 2003, 2003, 0925-0939.

McKittrick, B. A.; Stevenson, R. J. Chem. Soc., Perkin Trans. 1 1983, 475-482.

Jiang, J.; Biggins, J. B.; Thorson, J. S. J. Am. Chem. Soc. 2000, 122, 6803-6804.

Langenhan, J. M.; Griffith, B. R.; Thorson, J. S. J. Nat. Prod. 2005, 68, 1696-1711.

Thibodeaux, C. J.; Melancon, C. E., 3rd; Liu, H. W. Angew. Chem. Int. Ed. Engl. 2008, 47, 9814-9859.

Albermann, C.; Soriano, A.; Jiang, J.; Vollmer, H.; Biggins, J. B.; Barton, W. A.; Lesniak, J.; Nikolov, D. B.;

Thorson, J. S. Org. Lett. 2003, 5, 933-936.

21. Cheng, H.; Cao, X.; Xian, M.; Fang, L.; Cai, T. B.; Ji, J. J.; Tunac, J. B.; Sun, D.; Wang, P. G. J. Med. Chem. 2004, 48, 645-652.

22. Jacobsson, M.; Malmberg, J.; Ellervik, U. Carbohyd. Res. 2006, 341, 1266-1281.

23. Jensen, K. J. J. Chem. Soc., Perkin Trans. 1 2002, 2219-2233.

24. Dasgupta, S.; Rajput, V. K.; Roy, B.; Mukhopadhyay, B. J. Carbohyd. Chem. 2007, 26, 91-106.

25. Schmidt, R. R.; Michel, J.; Roos, M. Liebigs Ann. Chem. 1984, 1984, 1343-1357.

26. Jung, S.-H.; Cho, S.-H.; Hung Dang, T.; Lee, J.-H.; Ju, J.-H.; Kim, M.-K.; Lee, S.-H.; Ryu, J.-C.; Kim, Y. Eur. J. Med. Chem. 2003, 38, 537-545.

27. Gao, Q.; Lian, G.; Lin, F. Carbohydr. Res. 2009, 344, 511-515.

28. Nigudkar, S. S.; Parameswar, A. R.; Pornsuriyasak, P.; Stine, K. J.; Demchenko, A. V. Org. Biomol. Chem. 2013, 11, 4068-4076.

29. Zaffaroni, N.; Pennati, M. unpublished data

30. Fulmer, G. R.; Miller, A. J. M.; Sherden, N. H.; Gottlieb, H. E.; Nudelman, A.; Stoltz, B. M.; Bercaw, J. E.; Goldberg, K. I. Organometallics 2010, 29, 2176-2179.

31. Higashi, K.; Nakayama, K.; Shioya, E.; Kusama, T. Chem. Pharm. Bull. 1991, 39, 2502-2504.

32. Tsai, J.-H.; Behrman, E. J. Carbohydr. Res. 1978, 64, 297-301.

33. Binch, H.; Stangier, K.; Thiem, J. Carbohydr. Res. 1998, 306, 409-419.

34. Oyama, K.-i.; Kondo, T. Tetrahedron 2004, 60, 2025-2034.

35. Zhao, Y.; Biggins, J. B.; Thorson, J. S. J. Am. Chem. Soc. 1998, 120, 12986-12987 